\title{
Nejapa Tephra: The youngest (c. 1 ka BP) highly explosive hydroclastic eruption in western Managua (Nicaragua)
}

\author{
Juanita Rausch ${ }^{\mathrm{a}, *}$, Hans-Ulrich Schmincke ${ }^{\mathrm{b}}$ \\ a Département de Géosciences, Université de Fribourg, Chemin du Musée 6, 1700 Fribourg, Switzerland \\ b IFM-GEOMAR, Leibniz Institute for Marine Sciences,Wischhofstr. 1-3, 24148 Kiel, Germany
}

\begin{abstract}
Nejapa Maar $(2.5 \times 1.4 \mathrm{~km}$, c. $120 \mathrm{~m}$ deep $)$, the largest maar along the $15-\mathrm{km}$-long Holocene NejapaMiraflores Lineament (NML), is the source vent of the youngest relatively widespread basaltic tholeiitic tephra blanket (Nejapa Tephra: NT) in western central Nicaragua, as shown by isopachs and isopleths (Rausch and Schmincke, 2008). The NT covers an area of $>10 \mathrm{~km}^{2}$ in W/NW Managua. The minimum total magma volume erupted is estimated as $0.09 \mathrm{~km}^{3}$. Juvenile, dominantly slightly vesicular $(20-40$ vol.\%) basically tachylitic cauliflower-shaped lapilli with an average density of $2.1 \mathrm{~g} / \mathrm{cm}^{3}$, make up $>90 \mathrm{vol} . \%$ of the deposit, while lithoclasts comprise $<10$ vol.\% except proximally. This, the paucity of fine-grained tuffs and the dominant plane-parallel bedding all suggest fragmentation by shallow interaction of a rising magma starting to vesiculate and fragment pyroclastically with external water. The complex particles so generated erupted in moderately high eruption columns (at least 7-10 km) and were dominantly deposited as dry to damp, warm to cool fallout. Minor surge transport is inferred from fine-grained, locally cross-bedded tephra beds chiefly north of Nejapa and just west of Asososca Maars. Synvolcanic faulting along the NML is inferred. Faults in the study area indicate that activation of the N-S-trending Nejapa-Miraflores Fault (NMF), representing the western flank of Managua Graben, preceded deposition of NT and underlying Masaya Tuff (c.1.8 ka BP), Chiltepe Pumice (c. 1.9 ka BP) and Masaya Triple Layer (2.1 ka BP). The NT deposit is underlain regionally by a paleosol and topped by a soil. The basal paleosol contains pottery sherds made by the Usulután negative technique during the Late Formative period (700 BCE-300 CE) (2.7-1.7 ka BP). The soil overlying NT contains pottery related to the Ometepe technique dated as between 1350 and 1550 CE (650$450 \mathrm{a} \mathrm{BP})$. These, and the radiocarbon dates of the pottery-bearing paleosols (1245 \pm 125 and $535 \pm$ 110 a BP) obtained by Pardo et al. (2008) indicate that Nejapa Maar erupted between c. 1.2 and 0.6 ka BP. Future eruptions in this area of similar magnitude, eruptive and transport mechanisms would represent a major hazard and risk to the densely populated western suburbs of Managua, a city expanding rapidly westward. Assuming a similar eruption scenario, poor-quality roofs, common in Nicaragua, would be prone to collapse up to $12 \mathrm{~km}$ peripheral to Nejapa Maar or another close-by eruptive site, and buildings at a distance of up to $500 \mathrm{~m}$ are likely to be severely affected. In view of the past frequency of eruptions along the NML, further eruptions are likely to occur in the near future.
\end{abstract}

\section{Introduction}

Nicaragua has more than its share of natural hazards: earthquakes, volcanic eruptions, tsunamis, hurricanes and landslides. The highly vulnerable capital Managua, where more than one third of the country's population resides (c. 1.3 million), has been devastated repeatedly by major earthquakes, most recently in $1972(M=6.2)$ when practically the entire city was destroyed and 13000 people perished (Frischbutter, 2002; La Femina et al., 2002). Moreover, the city has been built on tephra deposits of several powerful Holocene

\footnotetext{
* Corresponding author.

E-mail address: Juanita.Rausch@unifr.ch (J. Rausch).
}

volcanic eruptions sourced in nearby volcanic centers, dominantly in active mafic Masaya volcano $20 \mathrm{~km}$ to the south and highly evolved Chiltepe volcanic complex $8 \mathrm{~km}$ to the north (Kutterolf et al., 2007, 2008). The city is expanding westwards across a major N-S-striking active volcano-tectonic zone known as the Nejapa-Miraflores Lineament (NML) (McBirney, 1956) (Fig. 1). The ages and eruptive processes of the numerous mafic volcanic centers along this lineament are thus of major interest because of the considerable volcanic hazards and risks to the expanding city and its population.

Previous summaries of the explosive volcanic eruptions in central Nicaragua (Freundt et al., 2006a; Kutterolf et al., 2007) confirmed that the last eruption along the Nejapa-Miraflores Lineament occurred less than $1.8 \mathrm{ka}$ ago, because this deposit is overlying the Masaya Tuff. Further work has shown, however, that the youngest powerful 


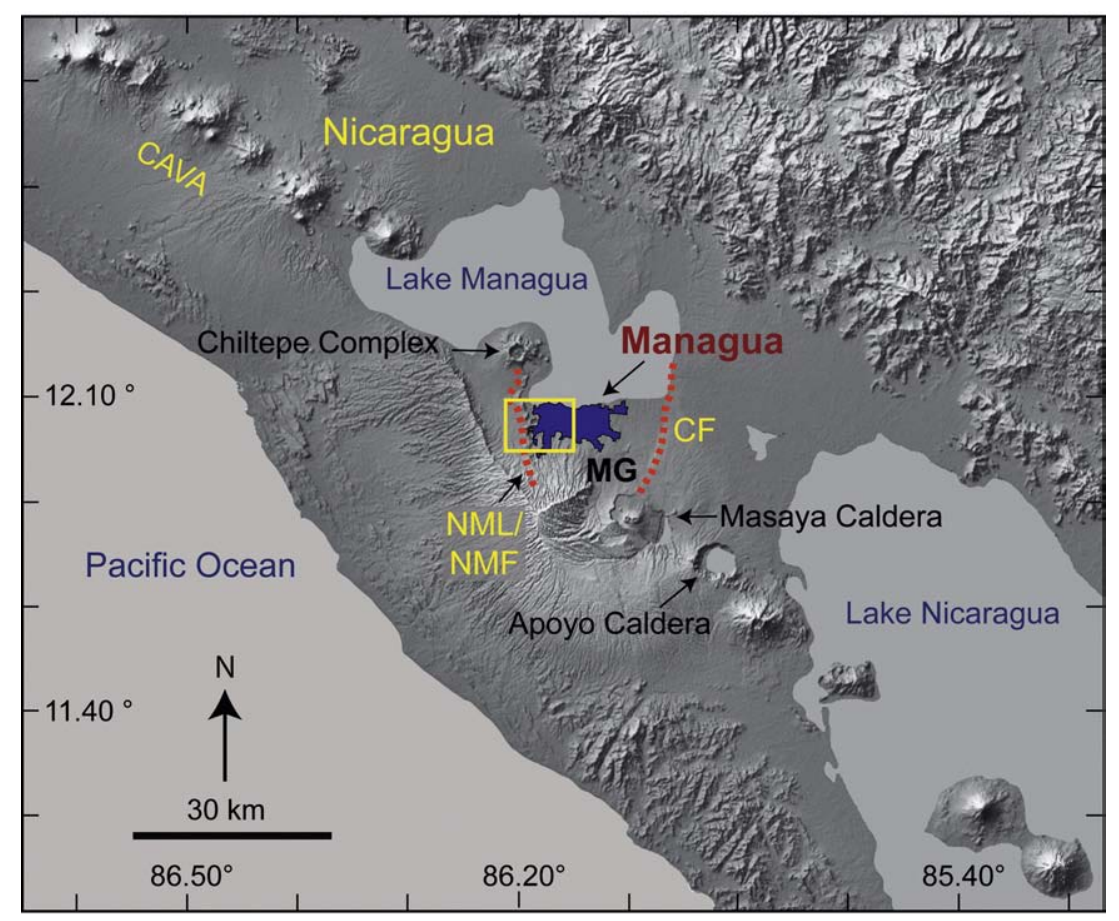

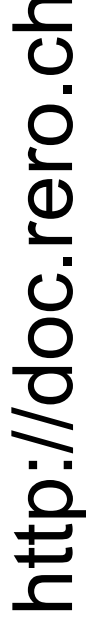

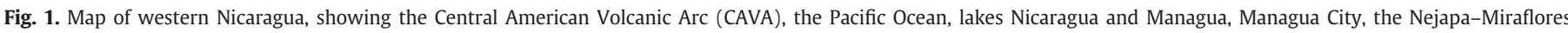

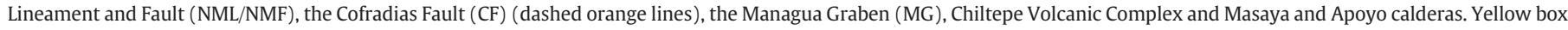
shows the study area in the NML.

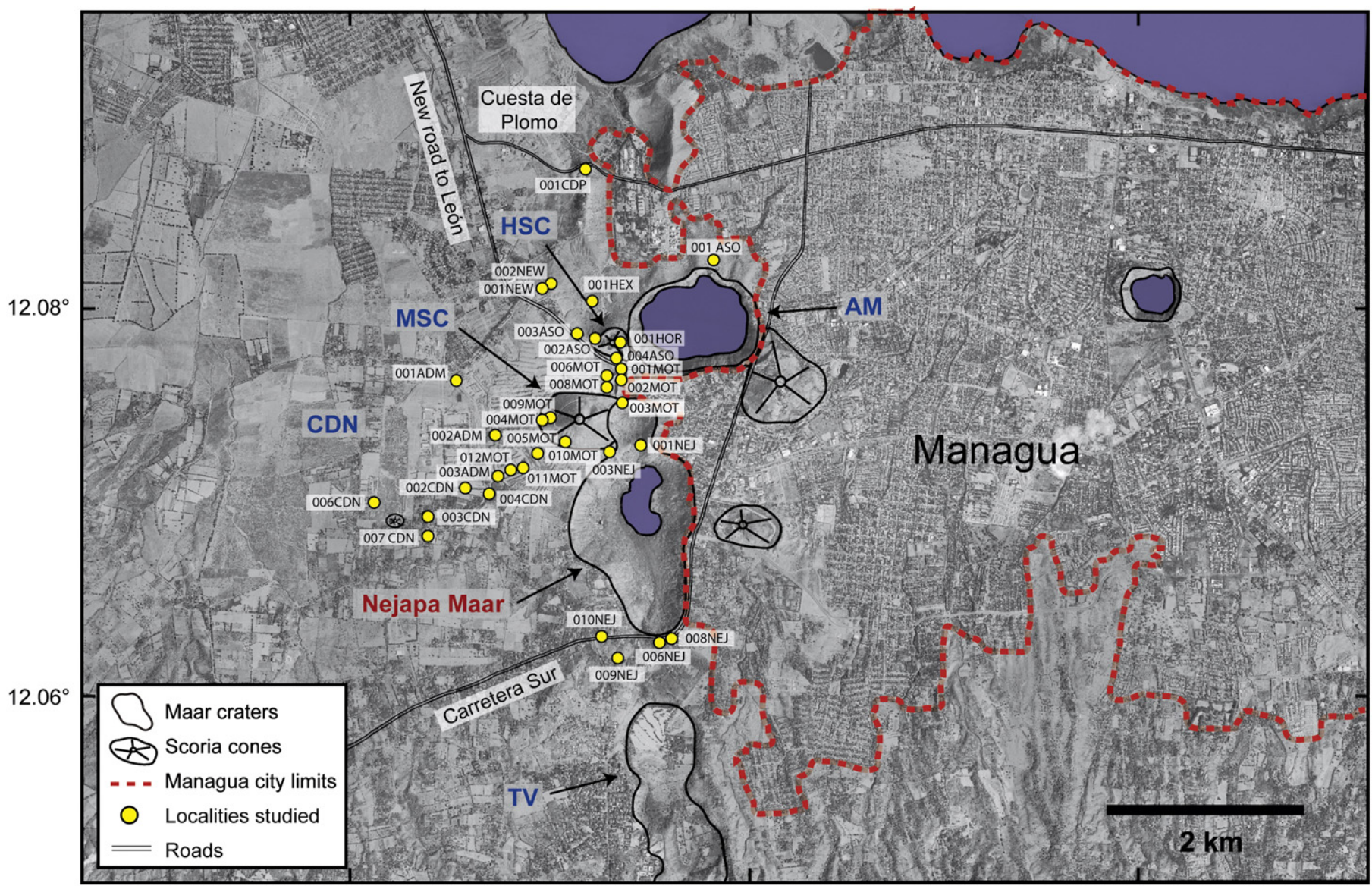

$86.20^{\circ}$

$86.18^{\circ}$

$86.16^{\circ}$

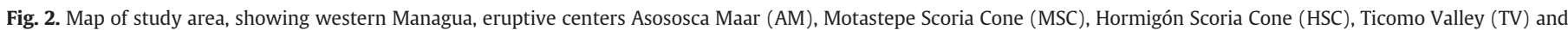

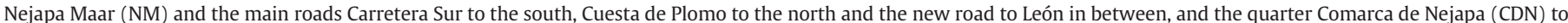
the west. Yellow points mark outcrops studied. 


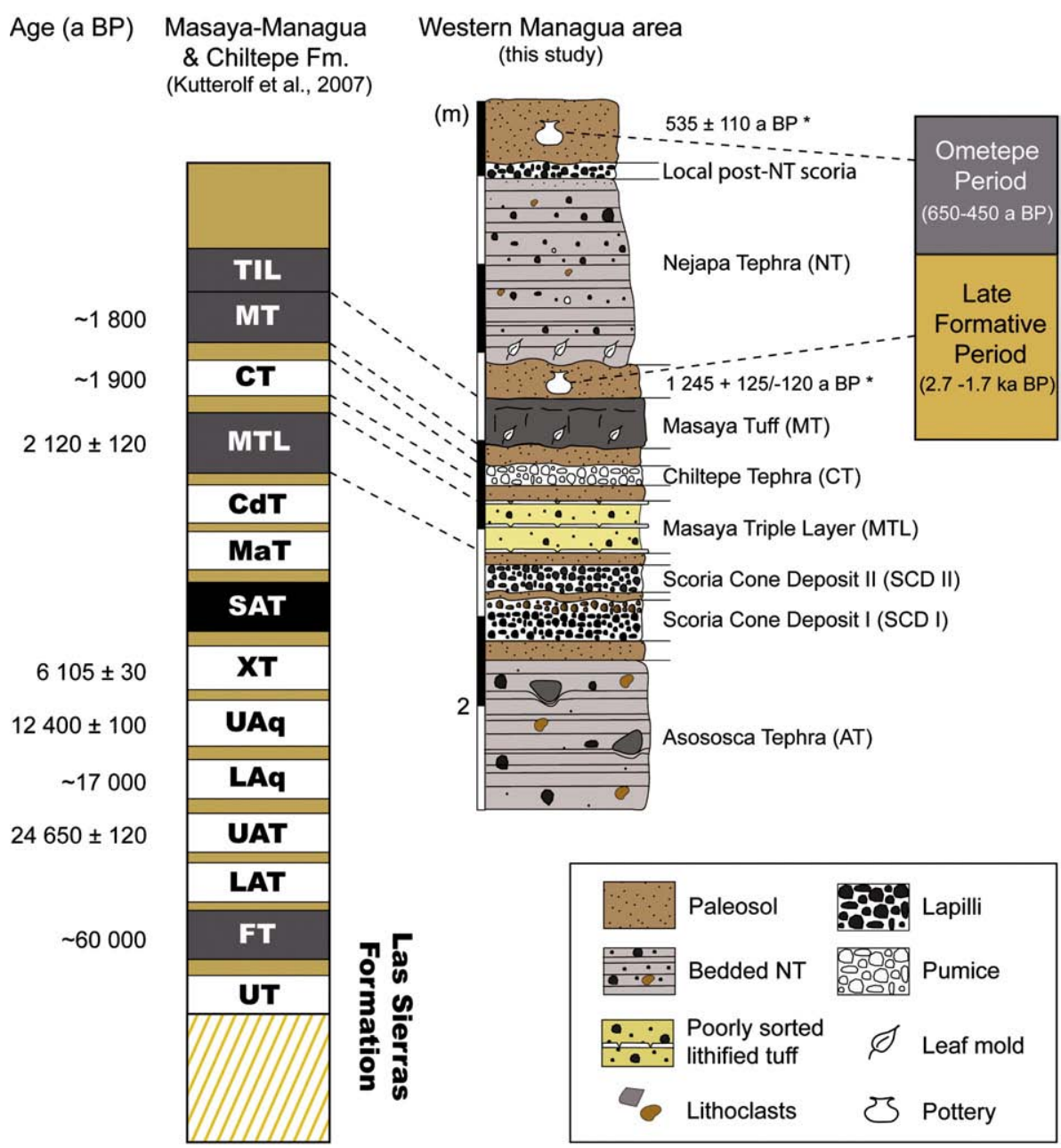

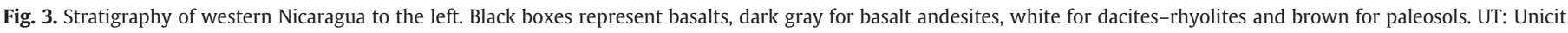

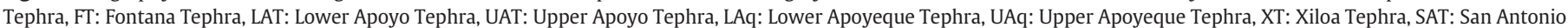

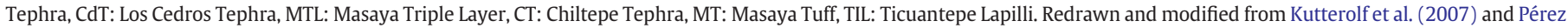

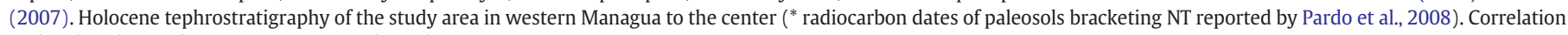
with cultural periods in Mesoamerica to the right.

explosive volcanic activity occurred as late as about $1 \mathrm{ka} \mathrm{BP}$, the eruptive center being the c. 120 -m-deep, elongate $(2.5 \times 1.4 \mathrm{~km})$ Nejapa Maar (Rausch and Schmincke, 2007, 2008) (Fig. 2). Here, we present a brief account of fragmentation, eruptive and transport processes and bulk rock composition with the purpose to help assess volcanic hazards and risks in western Managua. An area of c. $10 \mathrm{~km}^{2}$, limited in the south by Carretera Sur and in the north by Cuesta de Plomo, including Nejapa Maar (NM), Asososca Maar (AM), Motastepe Scoria Cone (MSC) and the quarter of Comarca de Nejapa (CDN) to the west was mapped and sampled in 2006 at a scale of 1:10000.

\section{Geological setting and previous work}

The Central American Volcanic Arc (CAVA) (Fig. 1), the result of subduction of the young $(<25 \mathrm{Ma}$ ) Cocos plate beneath the Caribbean plate at a rate of $\sim 8 \mathrm{~cm} / \mathrm{a}$ (De Mets, 2001), dominates the structure of western Nicaragua. The country is divided from west to east into the Pacific Coastal Plain, the Nicaragua Depression, the Interior Highland, and the Atlantic Coastal Plain (Weyl, 1980). The Nejapa-Miraflores Lineament (NML) (Fig. 1), a 15-km-long, N-S-trending volcano-tectonic offset in the $1200-\mathrm{km}$-long, NW-SE-striking CAVA, lies within the NWtrending, 45-50-km-wide, NW-trending Nicaraguan Depression, interpreted by McBirney and Williams $(1964,1965)$ as a graben and later reinterpreted by van Wyk de Vries (1993) as a low lying area bound by a volcanic highland region to the west and the Cofradia fault system to the east. The NML, first characterized and named Nejapa-Miraflores alignment by Ui (1972) and Walker (1984), extends from the Chiltepe peninsula to Ticomo valley. It hosts more than 20 overlapping Pleistocene-Holocene, dominantly hyaloclastite basaltic tephra rings, maars and scoria cones. Morphologically, elongated depressions up to 250 m deep (e.g. Ticomo valley) and 2 maars, the nearly circular Asososca Maar $(1.1 \times 0.8 \mathrm{~km}$, c. $100 \mathrm{~m}$ deep $)$ and the elongate Nejapa Maar $(2.5 \times 1.4 \mathrm{~km}, 120 \mathrm{~m}$ deep $)$ characterize the central part of the NML (Fig. 2). Williams (1952) argued that Asososca Maar and Nejapa Maar were basically formed by collapse and not by explosion. Nejapa Maar was interpreted by McBirney (1956) as basically a collapse feature initiated by minor explosions around a fissure with deposits extending no more than $200 \mathrm{~m}$ from the rim. McBirney also noted that the water in Nejapa Maar was unusually warm (up to $41{ }^{\circ} \mathrm{C}$ ) and basic ( $\mathrm{pH}=9.9$ to 10.0 ). Asososca Maar has since been interpreted as a maar crater. The youngest up to 20-m-thick bedded tephra deposits exposed basically west of Asososca Maar and along the new road to León and north of Motastepe Scoria Cone (MSC) (Fig. 2) were thought to have had their source in Asososca Maar (Weiss, 2004; Pardo et al., 2008, 2009). Our work clearly shows, however, that Nejapa Maar and not Asososca Maar is the source for the thick young tephra deposits mantling the area north and west of Nejapa Maar. The deposits form a thick blanket on adjacent Motastepe scoria cone (MSC) while very coarse-grained phreatomagmatic deposits most likely sourced in Asososca Maar, exposed in excellent road cuts mainly along the eastern part of the new road to León, are significantly 

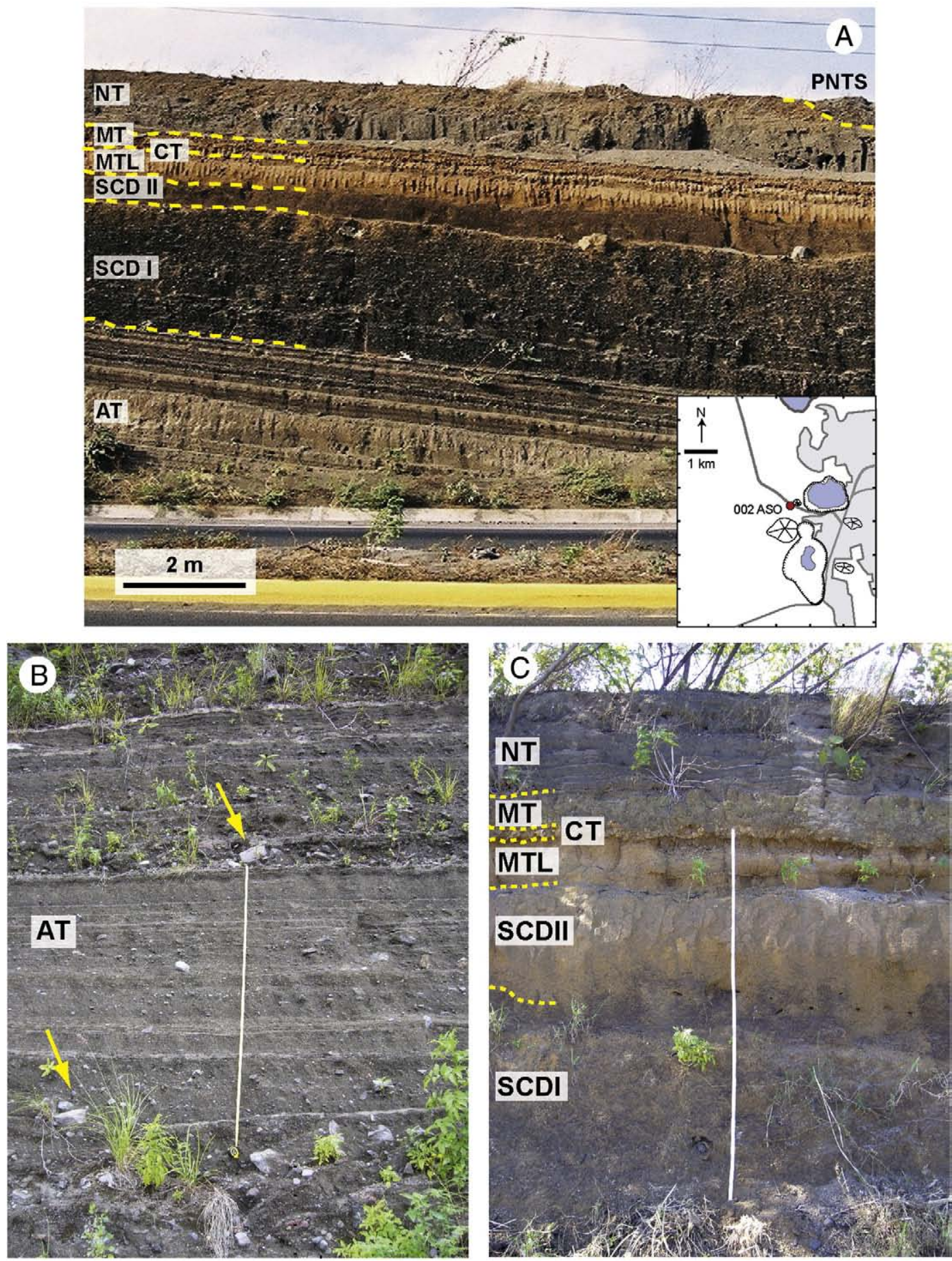

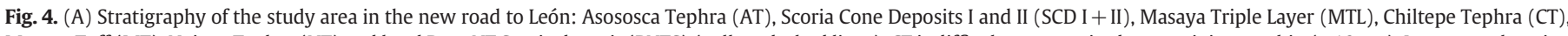

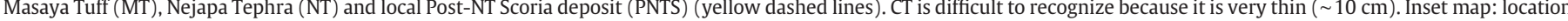

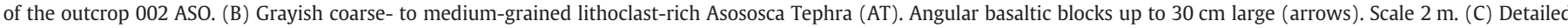
photograph showing Scoria Cone Deposits I and II (SCD I + II), Masaya Triple Layer (MTL), Chiltepe Tephra (CT), Masaya Tuff (MT) topped by Nejapa Tephra (NT). Scale 2 m.

older (see below). 15 Late Quaternary and Holocene tephra layers mostly of basaltic-andesitic and rhyodacitic composition occur in west-central Nicaragua, several of which are intercalated with NML volcanic deposits (Freundt et al., 2006a,b; Pérez and Freundt, 2006; Wehrmann et al., 2006; Kutterolf et al., 2007; Pérez, 2007; Kutterolf et al., 2008; Pérez et al., 2009; Schmincke et al., 2009a,b) (Fig. 3). Some aspects of the newly recognized Nejapa Tephra (NT) in the Managua area were presented elsewhere (Rausch and Schmincke, 2007, 2008) (Fig. 3).

\section{Holocene tephrostratigraphy around Managua}

The three youngest widespread tephra units in the Managua area are, from oldest to youngest, Masaya Triple Layer (MTL, $2.1 \mathrm{ka}$ ), Chiltepe Tephra (CT, c.1.9 ka) and Masaya Tuff (MT, c.1.8 ka) (Figs. 3 and 4). Recognition of these tephra beds in the field was fundamental in defining the newly recognized Nejapa Tephra (NT) even though all 3 directly underlying tephra units 


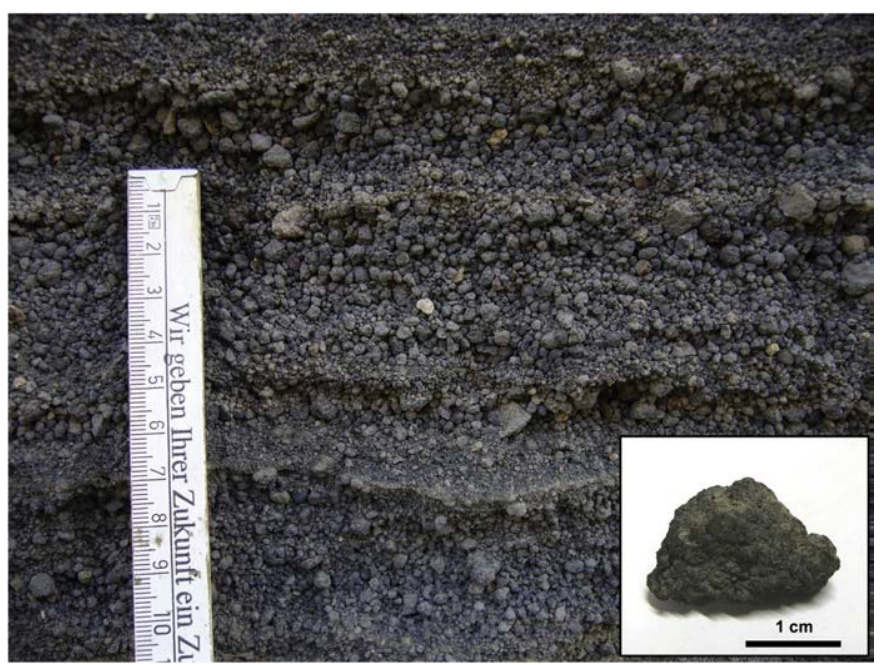

Fig. 5. Grayish, cauliflower-shaped lapilli-rich beds (>90 vol.\%) of the NT deposit. Inset: typical dense cauliflower-shaped lapillus of NT. are generally strongly weathered and have also been eroded locally. Older deposits in the study area - all sourced along the Nejapa-Miraflores Lineament (NML) - comprise 3 regional scoria cone deposits (Motastepe Scoria Cone Deposit (MSCD) and Scoria Cone Deposits I and II (SCD I + II)) and the underlying Asososca Tephra (AT), here newly defined (Figs. 3 and 4). Pardo et al. $(2008,2009)$ gave the name Asososca Tephra to the youngest tephra deposits in the same area studied by us because they thought the tephra was erupted in Asososca Maar, an interpretation based on impact sag geometries and dune crest migration. However, available outcrops are not suitable for this reconstruction because they are not oriented parallel to the assumed transport direction. Structures at the base of Nejapa Tephra interpreted by Pardo et al. (2008, fig. 17E) as surge structures are fallout beds draped over bushes grown in the underlying paleosol. Moreover, our isopach and isopleth maps unequivocally demonstrate that the youngest tephra deposits in the area were sourced in Nejapa Maar, hence the name Nejapa Tephra. Pardo et al. (2008, 2009) apparently lumped several tephra deposits of different age, as also shown by the
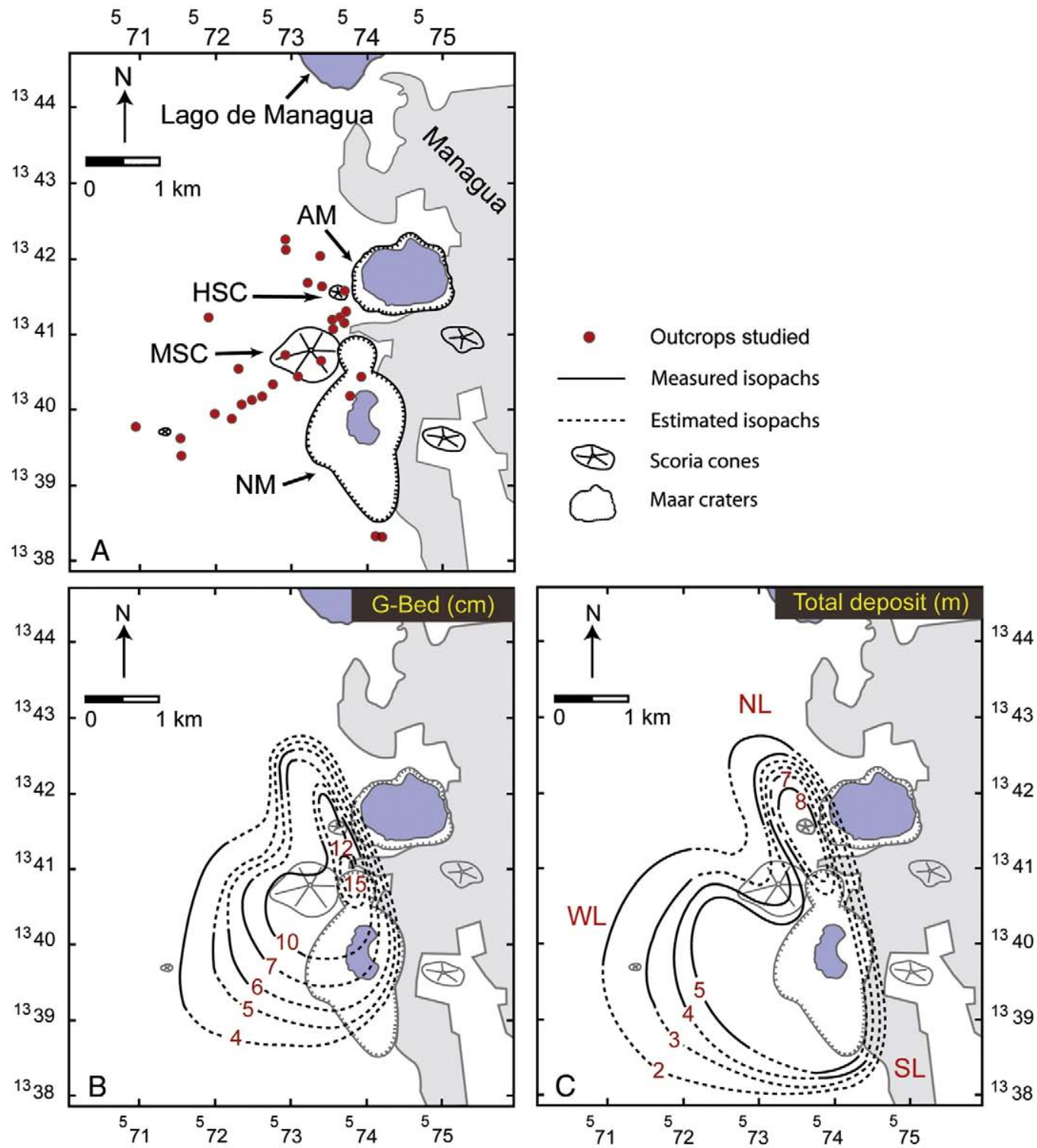

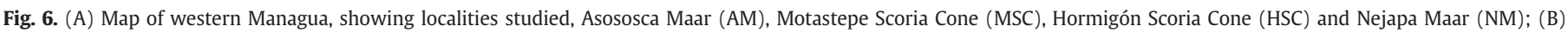
Isopachs in centimeters for the Nejapa Tephra marker bed G; and (C) Isopachs in meters for the total Nejapa Tephra. NL: Northern Lobe, WL: Western Lobe, SL: Southern Lobe. 


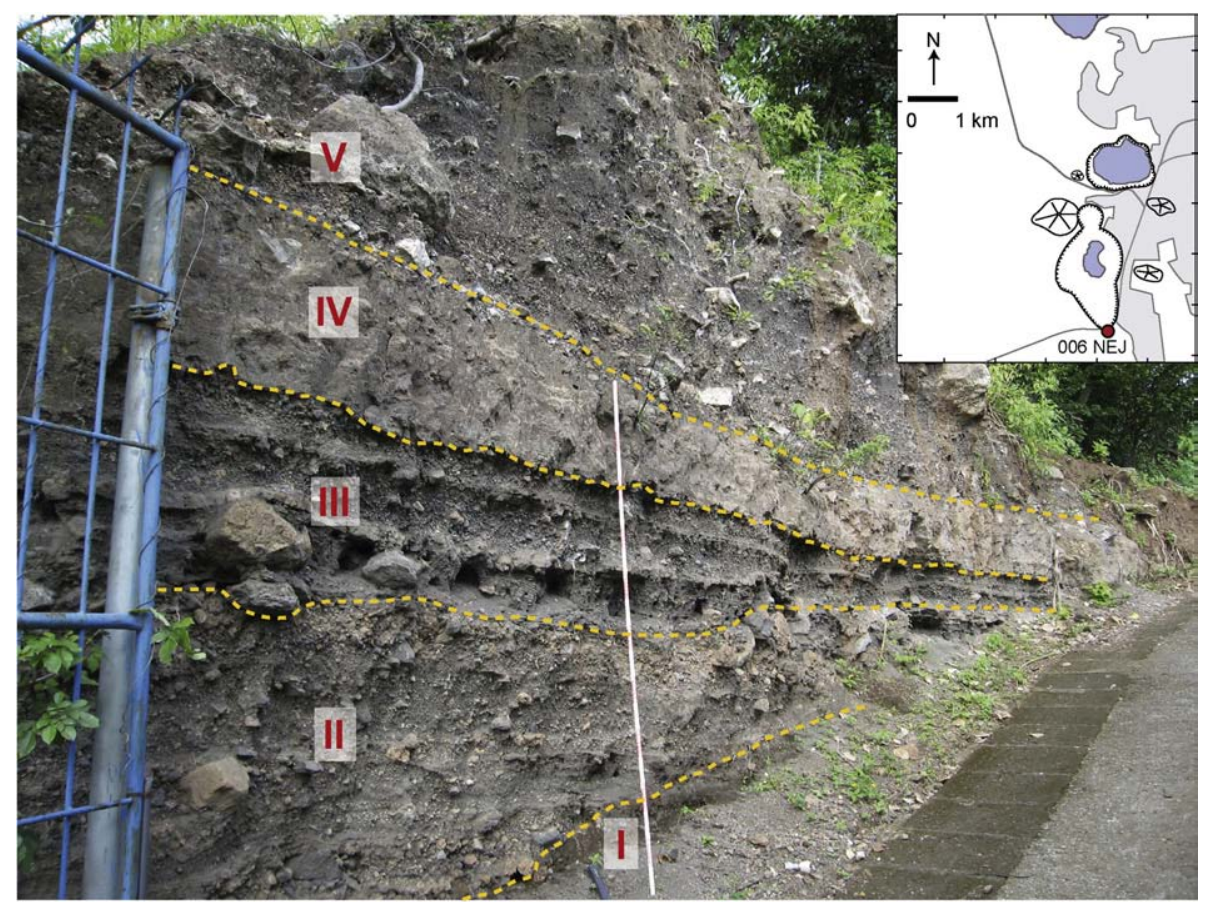

Fig. 7. Stratigraphy of the southern lobe of NT, showing units I-V (yellow dashed lines). Scale $2 \mathrm{~m}$. Inset map: location of the outcrop $006 \mathrm{NEJ}$.

heterogeneous chemical composition of juvenile clasts and the high abundance of lithoclasts they reported (see below). On the other hand, Scoria Cone Deposits I and II (here named) can be correlated with Tephra C (dated by Pardo et al., 2008 as $7175+$ 210/-205 a BP) and El Hormigón Tephra (dated by Pardo et al., 2008 as $6340 \pm 110$ a BP), respectively. The tephra deposit underlying the scoria cone deposits was most likely erupted from Asososca Maar based on the large diameter of lithic blocks (up to $1 \mathrm{~m}$ ) along the road to León, an outcrop situated just a few tens of meters south of Asososca Maar. Pardo et al. (2008) gave the name Northern Nejapa Tephra to the same deposit suggesting the northern Nejapa crater as the source vent (Fig. 3).

\subsection{Asososca Tephra (AT)}

AT in its proximal facies less than $100 \mathrm{~m}$ south and southwest of the rim of Asososca Maar is a gray, coarse-grained, poorlysorted, very lithoclast-rich deposit characterized by ballistically emplaced blocks up to $1 \mathrm{~m}$ in diameter and intercalated with finer-grained plane parallel and moderately sorted lapilli beds. Juvenile clasts make up $<70 \mathrm{vol} . \%$ of the deposit. The dominant lithoclast fragments are gray basaltic lava $(\mathrm{pl} \pm \mathrm{ol})$, minor brownish tuffs and rare scattered pumice lapilli (Fig. 4). The AT is well exposed on the new road to León (localities: 002 ASO, 004 ASO) (Fig. 4A, B), south of Asososca Maar (the type locality) and at Cuesta de Plomo (001 CDP), north of Asososca Maar. Both deposits were correlated based on similar lithology and stratigraphy. At Cuesta de Plomo, the $>15-\mathrm{m}$-thick AT sequence is topped by a lapilli fallout deposit consisting of highly vesicular pumice correlated to the Chiltepe Tephra (CT) (Fig. 3). At the new road to León (>10 m thick), AT and CT are separated from each other by two regional basaltic lapilli to bomb deposits (SCD I+ II) and the Masaya Triple Layer (MTL). Transport directions of ballistic impacts at the new road to León (from $\mathrm{E}$ to $\mathrm{W}$ ) and at Cuesta de Plomo (from E to W), and the occurrence of coarsegrained deposits and large blocks at proximal exposures suggest Asososca Maar as the source of the AT.

\subsection{Scoria Cone Deposit I (SCD I)}

SCD I is a regional well-sorted basaltic scoria lapilli deposit with bombs up to $20 \mathrm{~cm}$ in diameter, interpreted as fallout. The deposit consists entirely of juvenile clasts. Dominant phenocrysts are large plagioclase ( $\mathrm{pl}$ ) with minor olivine (ol). Scoria lapilli are agglutinated (up to $8 \mathrm{~cm} \varnothing$ ) and brownish in the uppermost weathered part of the deposit. The contact between SCD I and the overlying SCD II is strongly erosive. SCD I is at least $4 \mathrm{~m}$ thick at the new road to León (Figs. 3 and $4 A, C)$. It is probably sourced in El Hormigón scoria cone (Fig. 2) located within the NML west of Asososca Maar.

\subsection{Scoria Cone Deposit II (SCD II)}

SCD II is another regional finer-grained (MdØ $=-2)$ and wellsorted moderately vesiculated basaltic lapilli deposit interpreted as fallout. Juvenile clasts make up $>95$ vol.\%, while lithoclast fragments (pumice lapilli and felsic lavas) comprise $<5$ vol.\% of the SCD II. Dominant phenocrysts are pl. The top of the deposit is coarser grained and deeply weathered. SCD II is at least $1 \mathrm{~m}$ thick at the new road to León (Figs. 3 and 4A,C). The source is unknown but it may have been erupted from El Hormigón scoria cone as well (Fig. 2).

\subsection{Masaya Triple Layer (MTL)}

MTL (dated as $2120 \pm 120$ a BP) is mainly a fallout deposit ( 7 beds of scoria lapilli fallout, 4 major and several minor intercalated tuff beds) sourced in the western part of Masaya Caldera (Fig. 1), about $20 \mathrm{~km}$ south of Managua (Pérez and Freundt, 2006; Kutterolf et al., 2007, 2008; Pérez et al., 2009). Only a few outcrops (002 ASO, 004 ASO) were recognized west of Managua where the distal facies of MTL is 20 to $30 \mathrm{~cm}$ thick (Fig. 4A,C). The appearance of the MTL in the study area matches the description of Bice (1985). It consists of 2 thin $(1-2 \mathrm{~cm})$, massive, gray tuff beds intercalated with three thicker $(5-10 \mathrm{~cm})$ coarse ash beds (Fig. 4C). The composition of MTL is basaltic in the TAS diagram (Pérez and Freundt, 2006; Kutterolf et al., 2007) but it is appropriate to call it basaltic-andesitic because of its low $\mathrm{MgO}$ concentration ( $<5 \mathrm{wt} . \%)$. 


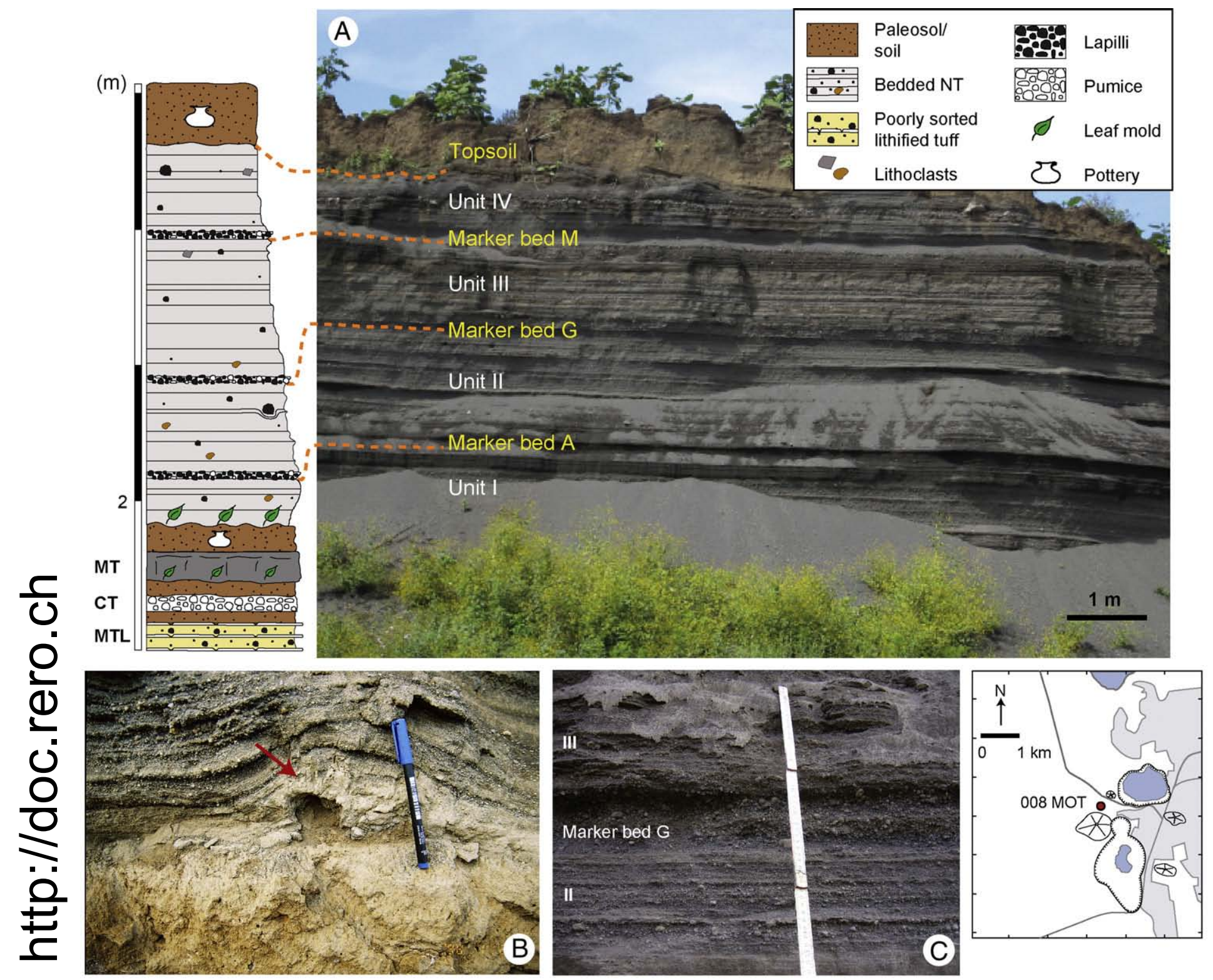

Fig. 8. (A) Stratigraphy of western and northern lobes of NT. NT is subdivided into units I, II, III and IV separated from each other by the marker beds A, G and M. Inset map: location of the outcrop 008 MOT; (B) close-up of undulated base of NT, caused by closely spaced bushes draped by fine-grained basal layers. Note fan-like molds of small branches; and (C) close-up of marker bed $\mathrm{G}$ intercalated between units II and III.

\subsection{Chiltepe Tephra (CT)}

The overlying CT consists proximally of a complex succession of ash and pumice lapilli fallouts, pyroclastic surge and flow deposits and a terminal phreatic tuff ring but the medial facies contains only the widespread plinian dacitic pumice lapilli fallout tephra. Apoyeque crater, part of the Chiltepe volcanic complex (Fig. 1) $8 \mathrm{~km}$ northwest of Managua, is the eruptive center of the CT (Kutterolf et al., 2007). The distal facies of CT west of Managua consists of a thin bed $(10-20 \mathrm{~cm})$ of highly vesicular pumice lapilli fallout characterized by large olivine xenocrysts (up to $1 \mathrm{~cm} \varnothing$ ), and phenocrysts comprising $\mathrm{pl}, \mathrm{opx}, \mathrm{cpx}$ and minor amph (Fig. 4C).

\subsection{Masaya Tuff (MT)}

MT, first described by Krusi and Schultz (1979), Williams (1983) and Bice (1985), is a gray, relatively poorly-sorted ash-rich basaltic-andesitic phreatomagmatic surge deposit with antidune structures concentric to Masaya Caldera (Fig. 1) (Pérez and Freundt, 2006). 5-20 vol.\% lithoclasts comprising basaltic lava and highly to poorly vesiculated lapilli, with phenocrysts of $\mathrm{pl}$, ol and minor cpx. West of Managua, MT, an indurated, approximately $40-\mathrm{cm}$-thick yellowish, laminated fine-grained tuff, represents the distal facies (Fig. 4C). The age of the MT (c.1.8 ka BP) is based on its stratigraphic position in marine sediments (Kutterolf et al., 2008).

\subsection{Motastepe Scoria Cone Deposit (MSCD)}

The MSCD is a well-sorted basaltic scoria lapilli deposit interpreted as fallout mantling Motastepe scoria cone. Dominant phenocrysts are ol and $\mathrm{pl}$. MSCD is locally exposed on the flanks of Motastepe scoria cone in sharp contact with the overlying thick blanket of Nejapa Tephra. Motastepe scoria cone (c. $650 \mathrm{~m} \emptyset, 140 \mathrm{~m}$ high) lies on the NML between Asososca Maar and Nejapa Maar and is interpreted as the source of this scoria deposit. 


\subsection{Post-NT Scoria Deposit}

A local, up to 40-cm-thick, well-sorted, slightly agglutinated basaltic scoria lapilli deposit interpreted as fallout is overlying NT at the new road to León (Figs. 3 and 4A). Dominant phenocrysts are pl and fresh ol ( $\sim 10$ vol.\%). The top of this post-NT scoria deposit is slightly weathered and strongly eroded. The source is unknown but it may have been erupted from one of the nearby scoria cones. Apparently there is no significant time break between the Nejapa and this very young eruption. Interestingly, scoria lapilli fallout layers are interbedded with gray hydroclastic Nejapa Tephra in the proximal southern facies.

\section{Nejapa Tephra (NT)}

Juvenile clasts of the newly defined Nejapa Tephra (NT) are mainly slightly vesicular (20-40 vol.\%) cauliflower-shaped lapilli (Fig. 5) and bombs with a density of 1.4 to $2.7 \mathrm{~g} / \mathrm{cm}^{3}$ and minor ash beds $\left(\operatorname{Md}_{\varnothing}>1\right)$. The lapilli show complex internal structures such as agglutination of multiple clasts with indistinct boundaries, variable vesicularity, modal amounts of phenocrysts and density. Dominant phenocrysts are ol, cpx and minor pl. Juvenile clasts make up more than 90 vol.\% of most of NT except in lithoclast-rich (>40 vol.\%) proximal deposits. Minor lithoclasts comprise angular basaltic lava, brownish weathered tuff and whitish pumice lapilli. Grayish, plain parallel-bedded, mostly well-sorted $\left(\sigma_{\varnothing}=0.7-1.5\right)$ cauliflowershaped lapilli-rich beds are characteristic of NT. Local cross-bedding and dune-like structures are restricted to fine-grained $\left(\operatorname{Md}_{\varnothing}>1\right)$ ash layers.

\section{Areal distribution}

Proximal to medial thickness data obtained from 30 outcrops (Fig. 6A,B,C) represent the minimum thickness of the NT, the base of the deposit not being exposed everywhere. Moreover, the top of the deposit is generally eroded. Thus, two isopach maps were constructed, one for the marker horizon G (Fig. 6B) and one for total NT thickness (Fig. 6C). Both clearly indicate Nejapa Maar as the source of NT and show similar dispersal patterns: (1) a main, almost semispherical lobe to the west and (2) a minor elongate lobe to the north.
A third minor lobe to the south (3) was recognized only in the isopach map constructed for the total thickness, because the marker horizon $G$ was not identified in the southern sector of Nejapa Maar.

\section{Depositional lobes}

Three depositional lobes show distinct facies. A particularly coarse-grained and lithoclast-rich facies is restricted to the maar rim in the south and southeast. A northern lobe is entirely transitional to the western lobe and represents a distinct facies developed in this elongate lobe. Most tephra erupted from Nejapa Maar was transported to the west (Fig. 6C).

\subsection{Southern lobe}

A particularly coarse-grained chaotic deposit at least $5 \mathrm{~m}$ thick is exposed at Carretera Sur (006 NEJ and 008 NEJ) south and southeast of Nejapa Maar in local cuts over a length of c. $500 \mathrm{~m}$ just above the steep southern slope of Nejapa Maar (Fig. 2). This deposit overlies a brownish paleosol developed on a pumice lapilli fallout unit (Upper Apoyeque Tephra, UAq) (Fig. 3), described in detail by Kutterolf et al. (2007). The uppermost layers of the proximal deposit are everywhere eroded. Although no outcrops were found more than c. $50 \mathrm{~m}$ south of the rim of Nejapa Maar, facies vary strongly over a distance of a few tens of meters. Nevertheless, 5 units were broadly distinguished from each other (Fig. 7):

(I) A basal coarse-grained, poorly-sorted unit up to $1 \mathrm{~m}$ thick with $<70$ vol.\% juvenile clasts is characterized by large lithoclasts (brownish tuff, mafic lava $(+\mathrm{pl})$ and pumice lapilli $(+\mathrm{pl}, \mathrm{hbl})$ ), some lava blocks exceeding $1.5 \mathrm{~m}$ in diameter. Juvenile lapilli are bread-crusted and poorly vesicular ( 20 vol.\%).

(II) The overlying unit II, up to $80 \mathrm{~cm}$ thick, consists of a c. $40-$ $\mathrm{cm}$-thick coarse-grained tephra (blocks up to $25 \mathrm{~cm} \varnothing$ ) dominated by lithoclast fragments ( 40 vol.\%) and sandwiched between two 10-30-cm-thick slightly cross-bedded coarse ash- to lapilli-sized deposits. Lithoclasts resemble those in unit I.

(III) Unit III, c. $50 \mathrm{~cm}$ thick, consists of a crudely bedded lithoclastrich ( $\sim 70$ vol.\%) basal unit ( $\sim 15 \mathrm{~cm}$ thick) and 2 better sorted

Table 1

Stratigraphic subdivision of the western lobe of NT (units I-IV: from base to top). CG: coarse-grained; MG: medium-grained; FG: fine-grained; CU: coarsening upward.

\begin{tabular}{|c|c|c|c|c|c|c|c|c|c|}
\hline $\begin{array}{l}\text { Unit/ } \\
\text { layer }\end{array}$ & $\begin{array}{l}\text { Thickness } \\
(\mathrm{cm})\end{array}$ & Eruption pulses & Sorting & $\begin{array}{l}\text { Grain size } \\
\text { (Md) }\end{array}$ & $\begin{array}{l}\text { Lithoclasts } \\
\text { (vol.\%) }\end{array}$ & $\begin{array}{l}\text { Juvenile clasts } \\
\text { (vol.\%) }\end{array}$ & $\begin{array}{l}\text { Phenocrysts } \\
\text { (ol, pl, and cpx) } \\
\text { (vol.\%) }\end{array}$ & Vesicularity & Bedding \\
\hline I & $\begin{array}{l}70 \text { proximal } \\
20 \text { distal }\end{array}$ & $\begin{array}{l}\sim 10 \text { gray } \\
\sim 20 \text { yellowish }\end{array}$ & Moderate & $\begin{array}{l}\text { CG layers: }-1 \\
\text { FG layers: }>1\end{array}$ & $\begin{array}{l}<10 \text { (tuff, pumice, } \\
\text { basaltic lavas) }\end{array}$ & $>90$ & & $\begin{array}{l}\text { Moderate to } \\
\text { poor }\end{array}$ & $\begin{array}{l}\text { CG layers well bedded; } \\
\text { some FG layers duned }\end{array}$ \\
\hline A & $\begin{array}{l}8 \text { proximal } \\
4 \text { distal }\end{array}$ & $\begin{array}{l}2 \text { dark gray CU } \\
\text { beds separated by } \\
\text { a FG layer }\end{array}$ & $\begin{array}{l}\text { Moderate to } \\
\text { well }(\sigma=1.5)\end{array}$ & $\begin{array}{l}\text { CG layers: }-1 \\
\text { FG layer: } 0\end{array}$ & $\begin{array}{l}<5 \text { (pumice, } \\
\text { basaltic lavas) }\end{array}$ & $>95$ & $21-26$ & $\begin{array}{l}\text { Moderate to } \\
\text { poor } \\
(20-30 \text { vol. \%) }\end{array}$ & $\begin{array}{l}\text { Well bedded reversely } \\
\text { graded fallout }\end{array}$ \\
\hline II & $\begin{array}{l}100 \text { proximal } \\
50 \text { distal }\end{array}$ & $\begin{array}{l}\sim 70 \text { yellowish/ } \\
\text { gray } \\
\sim 10 \text { grayish }\end{array}$ & Moderate & $\begin{array}{l}\text { FG layers }<1 \\
\text { CG layers: } 0\end{array}$ & $\begin{array}{l}<10 \text { (tuff, pumice, } \\
\text { basaltic lavas) }\end{array}$ & $>90$ & & $\begin{array}{l}\text { Moderate to } \\
\text { poor }\end{array}$ & $\begin{array}{l}\text { Some FG layers pinch } \\
\text { out and are normaly } \\
\text { graded; CG layers } \\
\text { reversely graded }\end{array}$ \\
\hline G & $\begin{array}{l}7 \text { proximal } \\
2.5 \text { distal }\end{array}$ & $\begin{array}{l}4 \text { dark gray CU } \\
\text { beds with a } \\
\text { basal FG layer }\end{array}$ & $\begin{array}{l}\text { Moderate to } \\
\text { well } \\
(\sigma=1.5)\end{array}$ & $\begin{array}{l}\text { CG layers: }-1 \\
\text { FG base }>0\end{array}$ & $\begin{array}{l}<5 \text { (tuff, pumice, } \\
\text { basaltic lavas) }\end{array}$ & $>95$ & $20-25$ & $\begin{array}{l}\text { Moderate to } \\
\text { poor } \\
(20-40 \text { vol. \%) }\end{array}$ & $\begin{array}{l}\text { Well bedded reversely } \\
\text { graded fallout }\end{array}$ \\
\hline III & $\begin{array}{l}70 \text { proximal } \\
40 \text { distal }\end{array}$ & $\begin{array}{l}\sim 70 \text { yellowish/ } \\
\text { gray } \\
\sim 10 \text { grayish base } \\
\text { and top: FG }\end{array}$ & $\begin{array}{l}\text { Moderate to } \\
\text { poor }\end{array}$ & $\begin{array}{l}\text { FG layers }>1 \\
\text { CG layers: } 0 \\
\text { base and } \\
\text { top }>2\end{array}$ & $\begin{array}{l}<10 \text { (tuff, basaltic } \\
\text { lavas) }\end{array}$ & $>90$ & & $\begin{array}{l}\text { Moderate to } \\
\text { poor }\end{array}$ & $\begin{array}{l}\text { CG layers well } \\
\text { bedded; some FG } \\
\text { layers duned }\end{array}$ \\
\hline M & $\begin{array}{l}7 \text { proximal } \\
3 \text { distal top } \\
\text { is eroded }\end{array}$ & $\begin{array}{l}2 \text { dark gray CU } \\
\text { beds separated by } \\
\text { a FG layer }\end{array}$ & Well $(\sigma=1.3)$ & $\begin{array}{l}\text { CG layers: } 0 \\
\text { FG layer }>2\end{array}$ & $\begin{array}{l}<5 \text { ( pumice, } \\
\text { basaltic lavas) }\end{array}$ & $>95$ & $32-40$ & $\begin{array}{l}\text { Moderate to } \\
\text { poor } \\
(25-30 \text { vol. \%) }\end{array}$ & $\begin{array}{l}\text { Well bedded reversely } \\
\text { graded fallout }\end{array}$ \\
\hline IV & $\begin{array}{l}\text { Varies largely } \\
\text { due to } \\
\text { erosion }\end{array}$ & $\begin{array}{l}\sim 20 \text { grayish } \\
\sim 10 \text { yellowish top: } \\
\text { silt/ash layers }\end{array}$ & $\begin{array}{l}\text { Moderate to } \\
\text { poor }\end{array}$ & $\begin{array}{l}\text { MG layers: } 1 \\
\text { FG layers > } 2\end{array}$ & $\begin{array}{l}<10 \text { (tuff, basaltic } \\
\text { lavas) }\end{array}$ & $>90$ & & $\begin{array}{l}\text { Moderate to } \\
\text { poor }\end{array}$ & $\begin{array}{l}\text { MG layers finely } \\
\text { bedded; FG layers and } \\
\text { top cross bedded }\end{array}$ \\
\hline
\end{tabular}



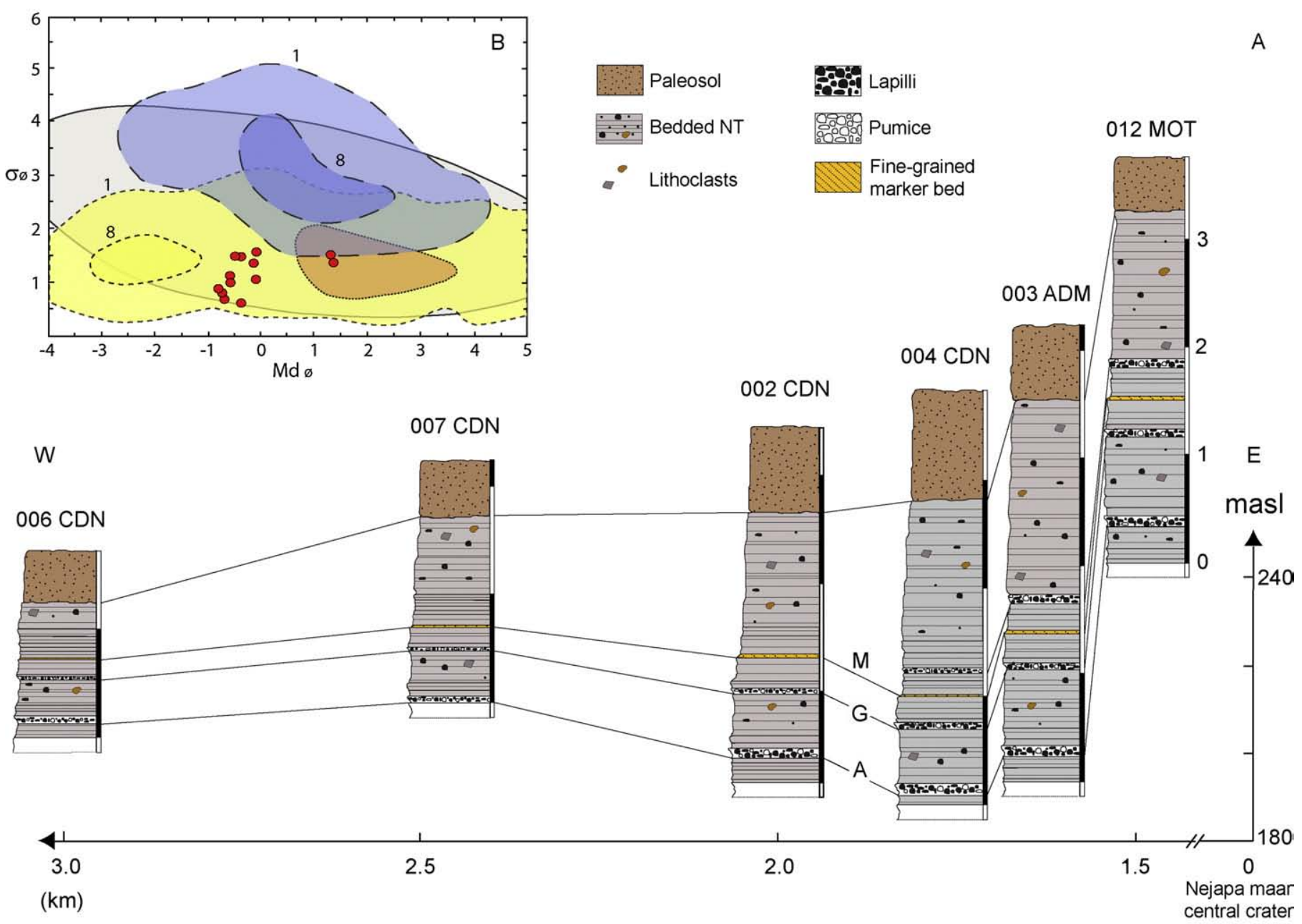

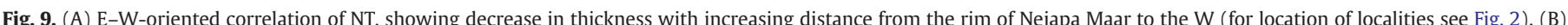

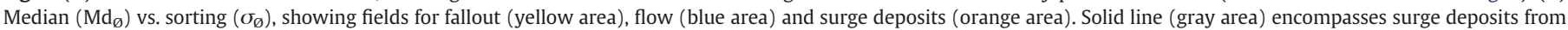
diverse sources. Modified from Walker (1971). This diagram indicates fallout as the main transport mechanism for NT.

lapilli deposits alternating with c. 5-cm-thick fine-grained yellowish massive tuffs. Dominant lithoclasts are brownish tuffs and mafic lavas up to $35 \mathrm{~cm} \emptyset$.

(IV) The overlying unit IV, up to $60 \mathrm{~cm}$ thick, is a massive, brownish, poorly-sorted lapilli-tuff deposit with scattered dm-sized blocks of mafic lavas.

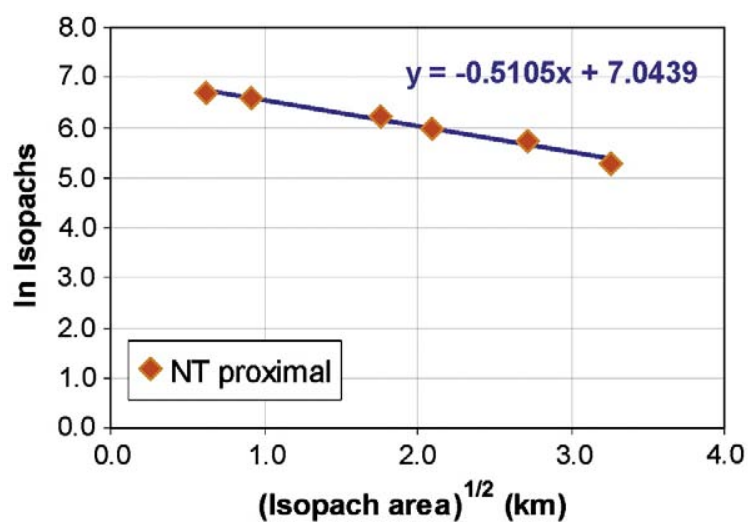

Fig. 10. Natural logarithm of isopach thickness vs. square root of isopach area enclosed based on isopach maps in Fig. 6. Volume calculated following Pyle $(1989,2000)$ and Fierstein and Nathenson (1992).
(V) The uppermost unit $\mathrm{V}$, up to $2.5 \mathrm{~m}$ thick, is a dominantly fairly massive basaltic lapilli/white scattered pumice deposit ("salt and pepper" appearance) with angular blocks up to $1.5 \mathrm{~m}$ in diameter, lithoclasts making up about 30 vol.\% of the deposit. The diameter of angular lava blocks seems to increase toward the top. Basaltic lapilli are highly vesicular (60-70 vol.\%) and the percentage of phenocrysts (dominantly pl and minor cpx and ol) is particularly low (<20 vol.\%) suggesting a more evolved composition. The occurrence of moderately to strongly vesicular juvenile basaltic lapilli is, however, remarkable because they are lacking in the deposits of the northern and main western lobes.

\subsection{Northern lobe}

North of Nejapa Maar, an elongated depositional lobe about $1 \mathrm{~km}$ wide extends for about $3 \mathrm{~km}$ northward, the tephra thickness in the farthest outcrops (002 NEW) still being at least $2 \mathrm{~m}$. The deposits are well exposed along the new road to León (002 MOT, 004 ASO and 001 HOR). Here, NT is up to $10 \mathrm{~m}$ thick and is a coarse-grained, well-bedded deposit. Most characteristic are weathered tuff fragments and scattered angular lava blocks up to $35 \mathrm{~cm}$ in diameter set in moderately- to wellsorted and well-bedded lapilli to coarse ash beds. Dune structures and cross-bedding are common in fine-grained beds. 
Table 2

Calculation of NT volume. For discussion see text and Fig. 10

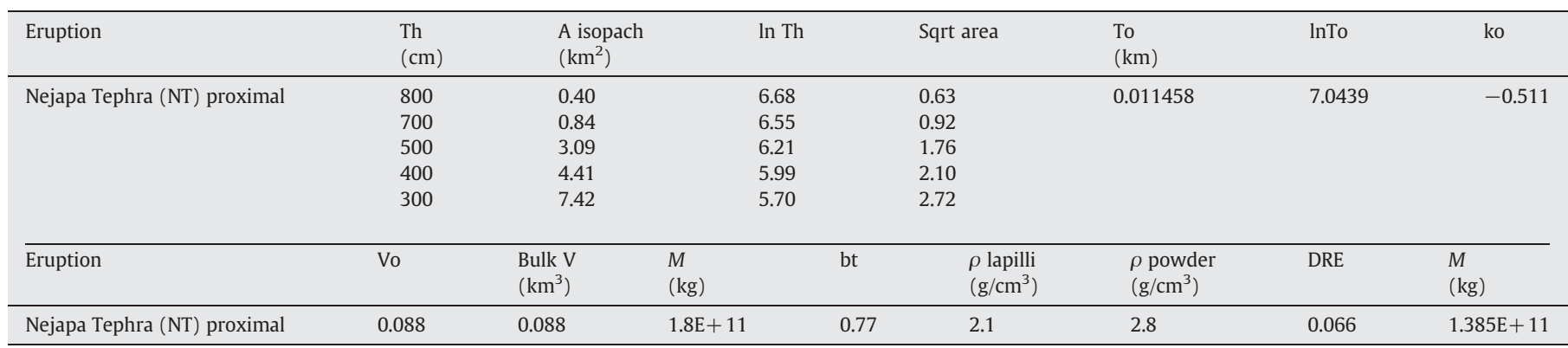

(1) Proximal facies: block-rich poorly exposed deposits containing large boulders up to $3.5 \mathrm{~m}$ in diameter (as also noted by Williams, 1952) are restricted to the northern and north-western slope of Nejapa Maar (001 NEJ) and limited to a narrow belt up to $200 \mathrm{~m}$ wide.
(2) Proximal/medial facies: up to $1 \mathrm{~km}$ north of Nejapa Maar (002 MOT and 004 ASO) ballistic impacts (up to $1 \mathrm{~m}$ in diameter) in coarse-grained, plane-parallel beds suggest transport from west to east, indicating Nejapa Maar as the most likely source. This proximal to medial deposit (up to $10 \mathrm{~m}$
A

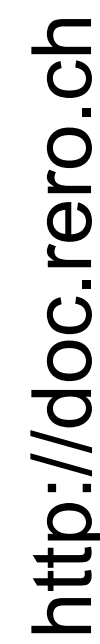

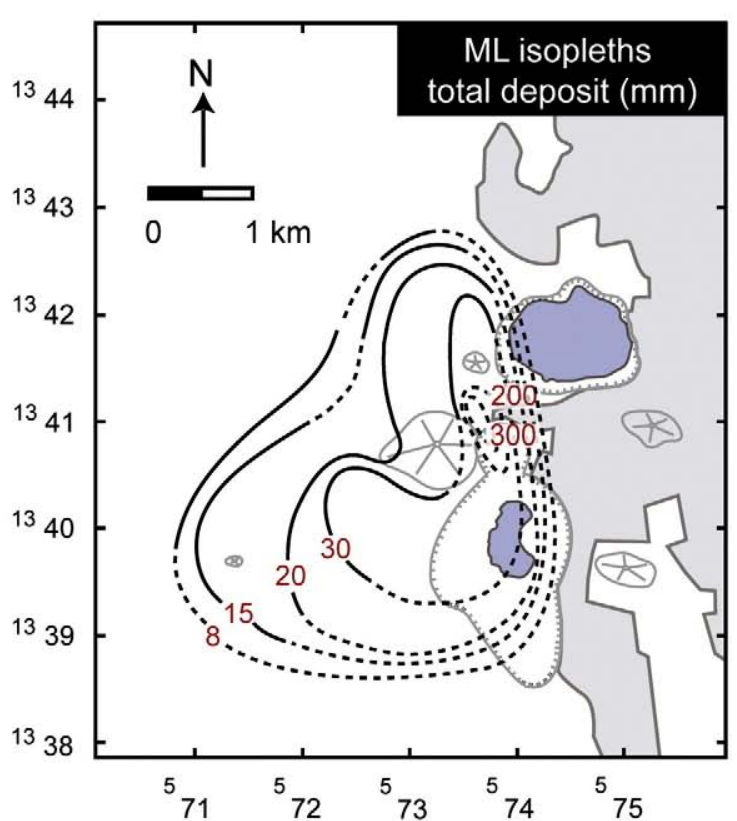

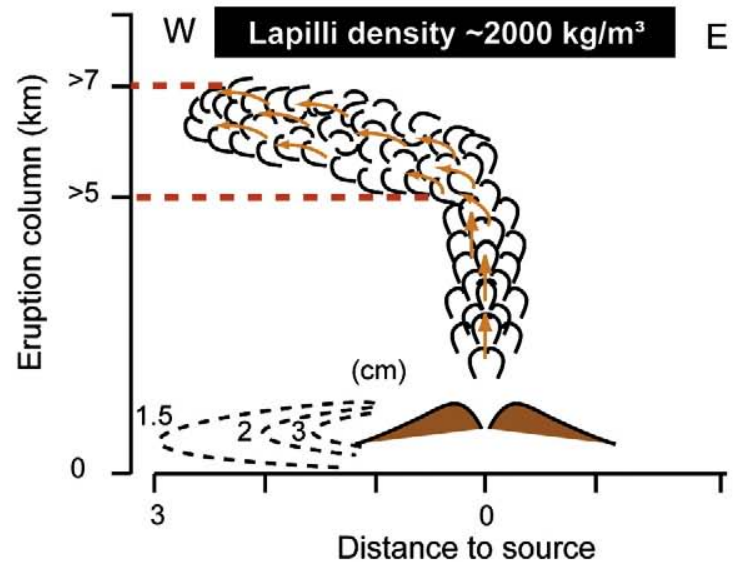

B

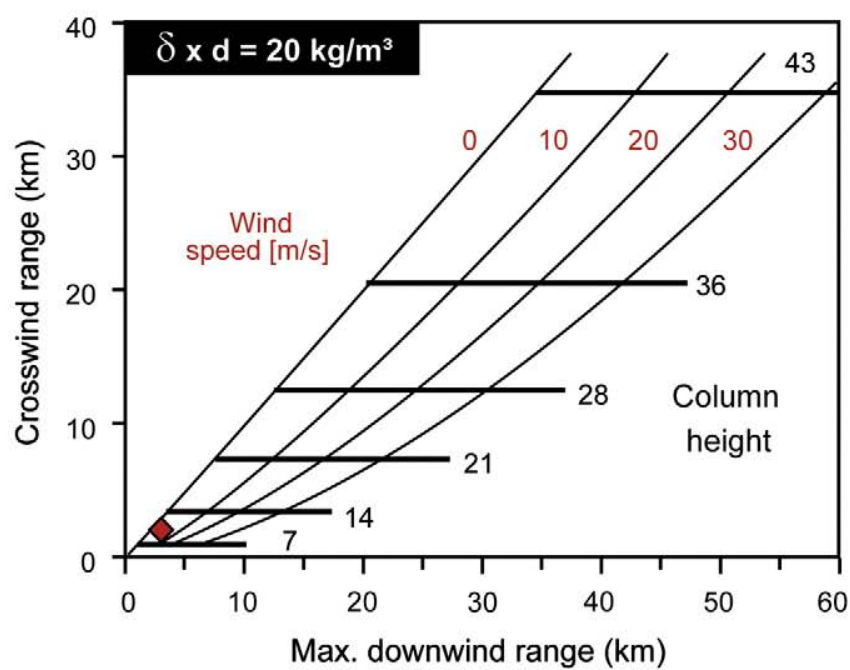

C

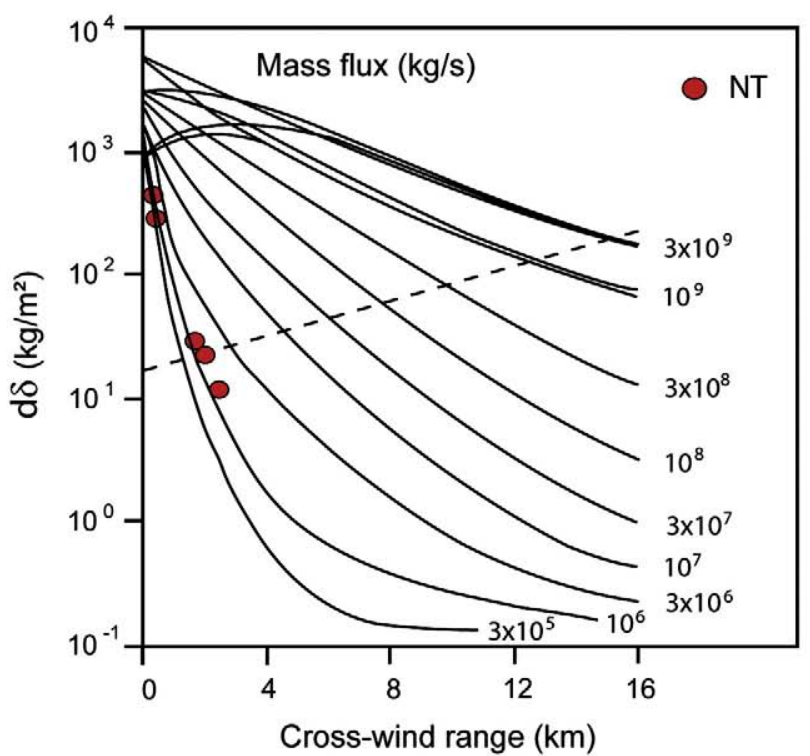

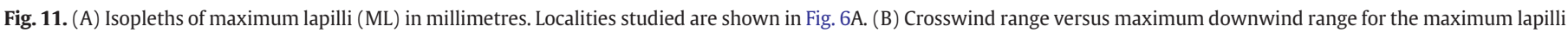

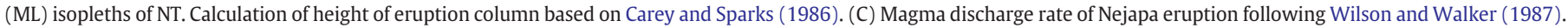




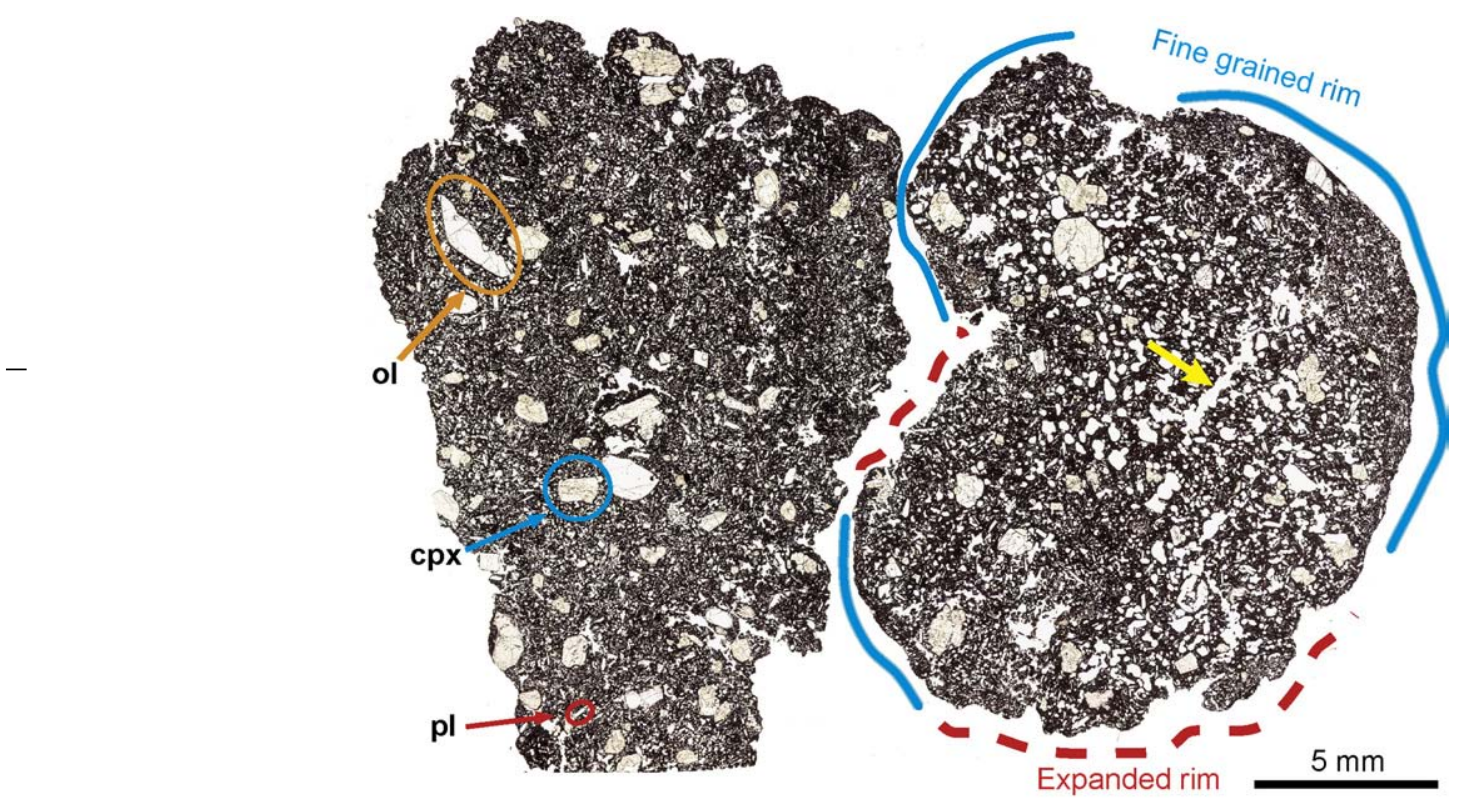

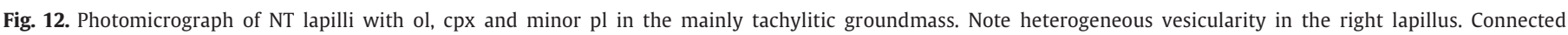

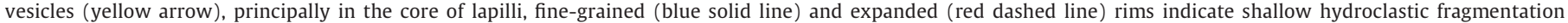
of a vesiculating magma. See text for discussion.

thick) has not been subdivided further because of poor accessibility.

(3) Medial/distal facies: outcrops 1.5-2.5 km north and northwest of Nejapa Maar show a finer-grained well-bedded deposit, up to $8 \mathrm{~m}$ thick medially (001 HOR, $001 \mathrm{HEX}$ ) and $2.5 \mathrm{~m}$ thick medially to distally (001 NEW, 002 NEW), characterized by $>90$ vol.\% of juvenile clasts and locally duned silt/ash-sized layers. Three coarser-grained lapilli marker horizons (Layer A, $\mathrm{G}$ and $\mathrm{M}$ ) are correlated with lapilli layers in the western lobe (Fig. 8A).

\subsection{Western lobe}

West of Nejapa Maar, a large nearly semi-spherical depositional lobe can be followed as far as $3 \mathrm{~km}$ from the vent (006 CDN, 001 $\mathrm{ADM}$ ), where NT is still at least $2 \mathrm{~m}$ thick. This western lobe is well exposed in western Managua in the area of Motastepe scoria cone and Comarca de Nejapa, allowing a detailed stratigraphic subdivision into four plane-parallel bedded lapilli units (I-IV) separated from each other by three coarser-grained well-sorted $(\sigma \sim 1.5)$ marker horizons consisting of $>90$ vol.\% cauliflower-shaped juvenile lapilli (Layers A, G and $\mathrm{M}$ ), well-correlated west and north of Nejapa Maar (Table 1 ; Figs. $6 \mathrm{~B}$ and $8 \mathrm{~A}$ ).

\subsubsection{Base of the deposit}

The up to 40 -cm-thick base of the deposit consists of poorly to moderately sorted fine ash-sized locally weakly cross-bedded layers $0.2-2 \mathrm{~cm}$ thick, intercalated with minor coarser-grained $\left(\operatorname{Md}_{\varnothing}=-1\right)$ layers $1-4 \mathrm{~cm}$ thick. Characteristic for the basal unit of the deposit is a locally duned fine ash layer $1 \mathrm{~mm}$ thick with an undulated base. The irregular morphology of the contact is basically due to small bushes rooted in a paleosol that had developed on Masaya Tuff (MT). These bushes are also characterized by fan-shaped molds of branches, leaf-imprints being common in the ash layers (Fig. 8B). The intercalated yellowish, poorlysorted duned layers decrease in thickness in "saddles" (site of former bushes) and increase in thickness in "valleys" spaced a few $\mathrm{cm}$ to $\mathrm{dm}$ apart; they even pinch out locally. The c. $40-\mathrm{cm}$ thick basal deposit shows a coarsening upward. The base of the deposit is best exposed (1) along the new road to León (002 ASO), (2) at El Hormigón scoria cone (001 HOR), (3) in the lowland west of Asososca Maar (001 HEX) and (4) in the highland west of Asososca Maar (002 NEW).

\section{Facies variations}

The total thickness of the NT west of Nejapa Maar ranges from $6 \mathrm{~m}$ at $1 \mathrm{~km}$ (008 MOT) to at least $2 \mathrm{~m}$ as far away as $3 \mathrm{~km}$ (006 CDN, 003 CDN) from the source (Fig. 6A). Thickness and grain size parameters (max. lapilli size $[\mathrm{ML}]$ (defined as the average of the 5 largest lapilli) and median grain size $[\mathrm{Md}]$ ) decrease exponentially from the rim of Nejapa Maar towards the west (Figs. 9A-11A). Marker horizons A, G and $\mathrm{M}$ and units I, II and III can be generally correlated for at least $3 \mathrm{~km}$ from the source. Layers M and unit IV are locally missing due to erosion. Variable degrees of erosion do not permit determination of the total thickness of the NT and characterization of the uppermost layers. Fine-grained, locally duned tuff beds thin rapidly with increasing distance from Nejapa Maar.

\section{Correlation between depositional lobes}

The marker horizons A, G and M of nearly identical lithology and appearance can be correlated between the western lobe and the medial/distal facies of the northern lobe, the northern lobe being transitional to the western lobe. The particularly coarsegrained lithoclast-rich deposit c. $1.5 \mathrm{~km}$ north of Nejapa Maar is interpreted as a local proximal facies of the NT. The proximal to medial thick deposits of the northern lobe lie in a morphologic depression west of Asososca Maar and north of Nejapa Maar, where fine-grained locally cross-bedded layers are concentrated, thinning with increasing distance from Nejapa Maar. A stratigraphic correlation between the proximal, extremely coarse-grained deposits south of Nejapa Maar and the relatively widespread tephra west and north of Nejapa Maar was impossible due to clear differences in the lithology, stratigraphy and chemical composition (see geochemistry). 

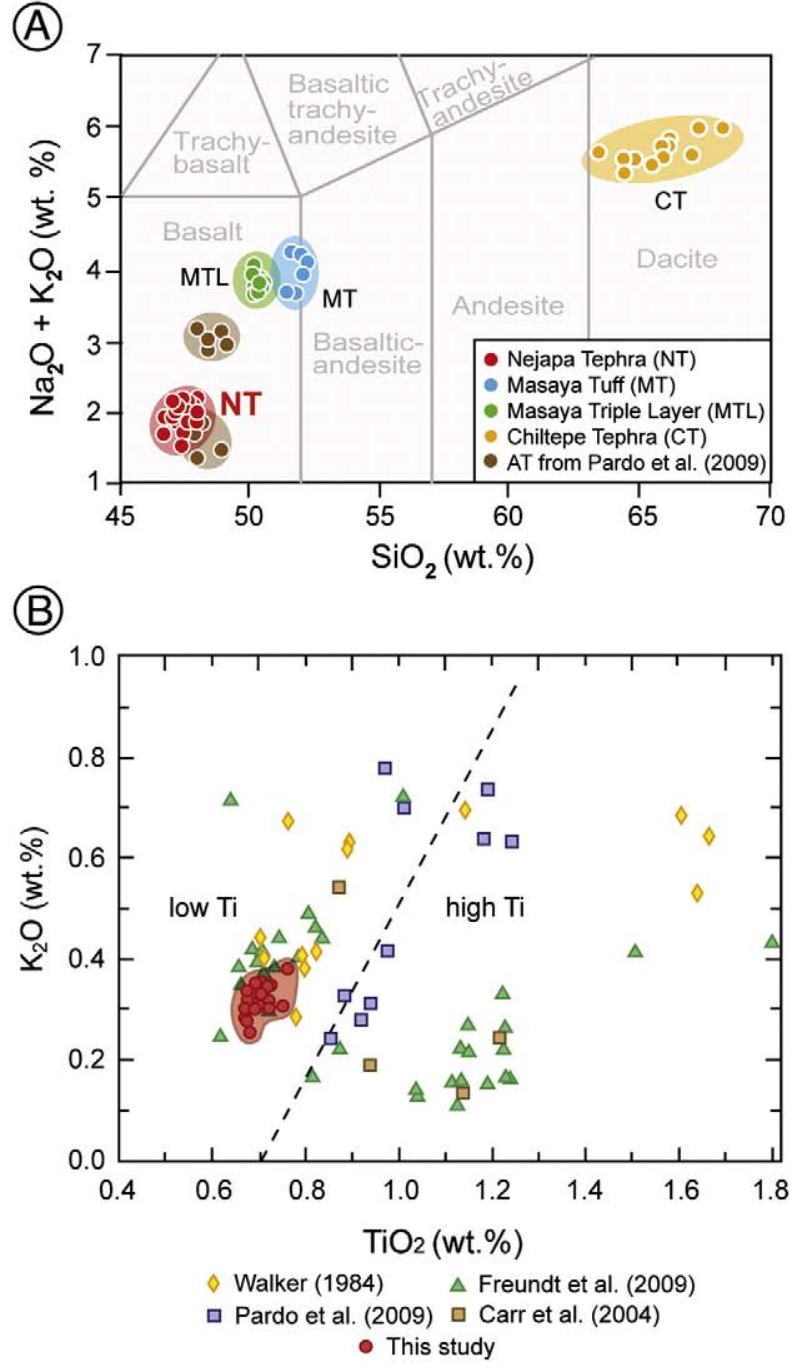

Fig. 13. (A) TAS diagram showing basaltic tholeiitic Nejapa Tephra (this study), MTL, MT and CT compositions (Kutterolf et al. 2007). Analyses by Pardo et al. (2009) for comparison. (B) Comparison of whole rock compositions of Nejapa Tephra (NT) (red dots) with Nejapa-Miraflores Lineament basalts from other authors (Walker, 1984; Carr et al., 2004; Freundt et al., 2009; Pardo et al., 2009) in a $\mathrm{Ti}_{2} \mathrm{O}$ vs. $\mathrm{K}_{2} \mathrm{O}$ diagram. Dashed line shows the boundary between high-Ti and low-Ti Nejapa-Miraflores basalts proposed by Walker (1984).

\section{Eruption parameters}

\subsection{NT volume}

Isopach thickness and areas enclosed (Fig. 6C) were used for estimating the NT volume following Pyle $(1989,2000)$ and Fierstein and Nathenson (1992) (Fig. 10). A bulk deposit volume of at least $0.09 \mathrm{~km}^{3}$ was calculated. Dense rock equivalent (DRE) of erupted magma was estimated as at least $0.07 \mathrm{~km}^{3}$ (see Table 2).

\subsection{Direction and height of eruption column}

We infer dominant wind directions to the west and northwest at the time of the eruption. This was deduced assuming that NT was mostly transported as fallout - as shown by the exponential decrease of thickness (Fig. 10) and the median ( $\left.\mathrm{Md}_{\varnothing}\right)$ vs. sorting $\left(\sigma_{\varnothing}\right)$ behavior (Fig. 9B). The long-term data of wind conditions in Nicaragua from the Climate Diagnostic Center (NOAA-CIRES, 2001; Kutterolf et al., 2007) confirms that tropospheric winds blow mainly toward the west and northwest all year round. Isopleths of maximum lapilli (ML) were constructed (Fig. 11A) to determine the height of the eruption column. The obtained data, e.g. isopleth area $\left(\mathrm{km}^{2}\right)$, max. downwind range $(\mathrm{km})$ and crosswind range $(\mathrm{km})$, were plotted and compared with eruption column models of Carey and Sparks (1986) and Wilson and Walker (1987). A minimum eruption column height of 7 to $10 \mathrm{~km}$ (Fig. 11B) and a magma discharge rate of 1 to $2 \times 10^{6} \mathrm{~kg} / \mathrm{s}$ (Fig. 11C) were estimated. An average lapilli density of $2.1 \mathrm{~g} / \mathrm{cm}^{3}$ was used.

\section{Petrography and mineralogy of the NT}

Juvenile NT lapilli making up about 90 vol.\% in the northern and 30 vol.\% in the southern lobe are mineralogically and chemically basalts. Phenocrysts (12 to $40 \mathrm{vol} . \%$ ) in the chiefly tachylitic groundmass are dominantly olivine (ol) and clinopyroxene (cpx) with minor plagioclase (pl) (Fig. 12). Sideromelane ( $<1$ vol.\%) occurs as glass inclusions in ol and cpx (Fig. 12) and in minor amounts at the rims of the lapilli. Complex phenocryst aggregates composed of ol, cpx and pl occur in almost all 15 thin sections studied. The groundmass is rich in pl and ol microlites with minor cpx, making up 10-20 vol.\%. Plagioclase microlites are commonly aligned. The vesicularity of the lapilli varies widely from 17 to 70 vol.\%, differing also significantly within the same layer and even individual lapilli (Fig. 12); vesicularity around $30 \mathrm{vol} . \%$ is most common. Vesicles are generally ragged and irregular; some vesicles are connected, principally in the cores of lapilli (Fig. 12). Many lapilli show a fine-grained crust and expanded rims (Fig. 12). The internal structures of most lapilli are very complex, several being composed of smaller agglutinated lapilli with mostly diffuse boundaries between the lapilli resembling the composite lapilli described by Bednarz and Schmincke (1990). Agglutination probably occurred at high temperature within the turbulently churning and vesiculating magma. Juvenile clasts in the southern and west/northwestern lobes differ significantly from each other petrographically, mineralogically and chemically.

\subsection{Southern Group (SG) and Western/Northwestern Group (W/NWG)}

The southern deposits consist of $<80$ vol.\% juvenile clasts and 20-40 vol.\% lithoclast fragments while juvenile clasts make up about 90-99 vol.\% of the deposits W and NW of Nejapa Maar. Lithoclasts of both groups comprise brownish weathered tuffs, pumice lapilli and moderately vesicular ( 40 vol.\%) pl-rich ( $\sim 10$ vol.\%) mafic lavas. The tachylite percentage (groundmass) of juvenile clasts of the southern deposits varies widely from 45 to $7 \mathrm{vol} \%$ decreasing towards the top of the deposit. In the W/NW deposits, tachylite also decreases upward from 60 to 40 vol.\%. Lapilli at the base of the southern deposits contain up to 40 vol.\% phenocrysts, mostly complex subhedral ol, cpx and minor pl, up to $2 \mathrm{~mm}$ large. The percentage of phenocrysts decreases upward to 23 vol.\%. Phenocrysts in the uppermost layers are anhedral and slightly smaller. Complex phenocryst aggregates (up to $1 \mathrm{~cm}$ large) of ol and cpx with minor pl are common.

West and northwest of Nejapa Maar, phenocryst aggregates (up to $8 \mathrm{~mm}$ large) and subhedral phenocrysts (up to $4 \mathrm{~mm}$ ) are most common in the lapilli of the lower layers while phenocrysts in the lapilli of the uppermost layers are mostly anhedral. The modal percentage of phenocrysts and phenocryst size decrease upward from 30 to 20 vol.\% and from 2 to $0.5 \mathrm{~mm}$ in diameter. Dominant microlites in both groups are pl with minor ol and cpx. In general, the percentage of microlites in the groundmass decreases upward. Both the $\mathrm{S}$ and the W/NW deposits are characterized by a change upward to less mafic composition expressed mineralogically by $<1$ vol.\% of olivine. On the other hand, ol microlites in lapilli of upper layers are more common than in lower layers. 

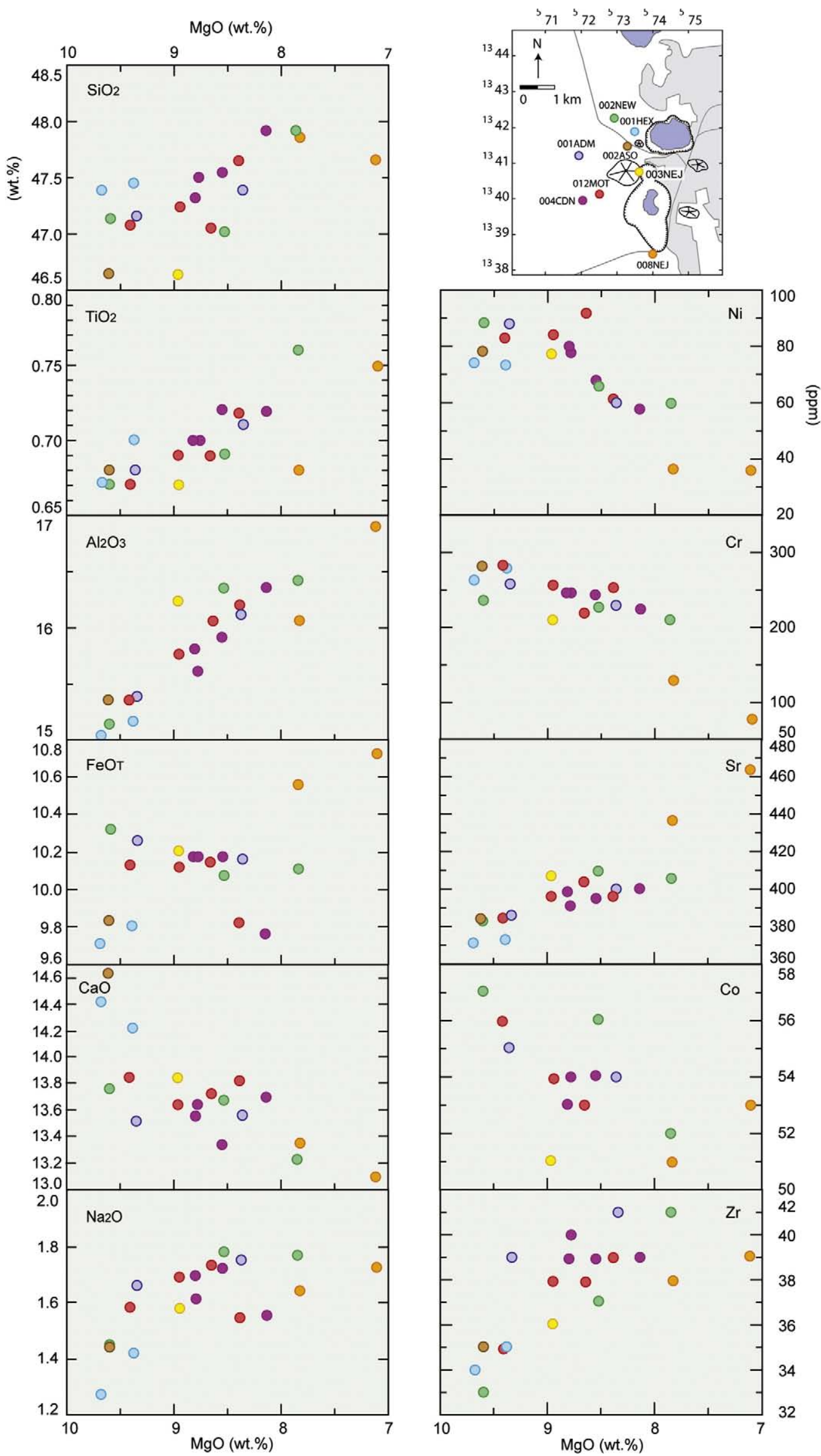

Fig. 14. Whole rock major and trace elements analyses (XRF) of NT. Major elements in wt.\%, trace elements in ppm. 
Table 3

Major and trace elements analyses of NT.

\begin{tabular}{|c|c|c|c|c|c|c|c|c|c|c|c|c|c|c|c|c|c|c|c|}
\hline \multirow[b]{2}{*}{ Locality } & \multirow[b]{2}{*}{003 NEJ } & \multirow[b]{2}{*}{012 MOT } & \multicolumn{15}{|c|}{ W/NW group } & \multirow{3}{*}{$\begin{array}{l}\text { S group } \\
008 \text { NEJ } \\
2006-12- \\
07-07\end{array}$} & \multirow[b]{3}{*}{$\begin{array}{l}2006-12- \\
18-02 a\end{array}$} \\
\hline & & & \multirow[b]{2}{*}{$\begin{array}{l}\text { 2006-12- } \\
\text { 07-03 b }\end{array}$} & \multirow[b]{2}{*}{$\begin{array}{l}\text { 2006-12- } \\
07-02\end{array}$} & \multirow[b]{2}{*}{$\begin{array}{l}\text { 2006-12- } \\
07-01\end{array}$} & \multirow{2}{*}{$\begin{array}{l}\text { 001 HEX } \\
\text { 2006-11- } \\
30-02\end{array}$} & \multirow[b]{2}{*}{$\begin{array}{l}\text { 2006-11- } \\
30-03\end{array}$} & \multirow{2}{*}{$\begin{array}{l}\frac{01 \text { ADM }}{2006-12-} \\
14-02 \\
\end{array}$} & \multirow[b]{2}{*}{$\begin{array}{l}\text { 2006-12- } \\
14-01\end{array}$} & \multirow{2}{*}{$\begin{array}{l}\text { 002 ASO } \\
2006-12- \\
05-02\end{array}$} & \multirow{2}{*}{$\begin{array}{l}\frac{002 \text { NEW }}{2006-12-} \\
05-08 \\
\end{array}$} & \multirow[b]{2}{*}{$\begin{array}{l}\text { 2006-12- } \\
\text { 05-09 }\end{array}$} & \multirow[b]{2}{*}{$\begin{array}{l}\text { 2006-12- } \\
\text { 05-10 } \\
\end{array}$} & \multirow{2}{*}{$\begin{array}{l}\frac{04 \mathrm{CDN}}{2006-12-} \\
11-01\end{array}$} & \multirow[b]{2}{*}{$\begin{array}{l}2006-12- \\
10-03 \text { b } \\
\end{array}$} & \multirow[b]{2}{*}{$\begin{array}{l}\text { 2006-12- } \\
10-02 \\
\end{array}$} & \multirow[b]{2}{*}{$\begin{array}{l}\text { 2006-12- } \\
10-01 \\
\end{array}$} & & \\
\hline Sample & $\begin{array}{l}2006-11- \\
24-03\end{array}$ & $\begin{array}{l}\text { 2006-12- } \\
07-06\end{array}$ & & & & & & & & & & & & & & & & & \\
\hline & & $\sim$ base & $\begin{array}{l}\text { marker } \\
\text { bed G }\end{array}$ & $\begin{array}{l}\text { yellowish } \\
\text { bed }\end{array}$ & $\sim$ top & $\begin{array}{l}\text { marker } \\
\text { bed G }\end{array}$ & $\begin{array}{l}\text { marker } \\
\text { bed } A\end{array}$ & $\begin{array}{l}\text { marker } \\
\text { bed A }\end{array}$ & $\begin{array}{l}\text { marker } \\
\text { bed G }\end{array}$ & $\sim$ base & $\begin{array}{l}\text { marker } \\
\text { bed } A\end{array}$ & $\begin{array}{l}\text { marker } \\
\text { bed G }\end{array}$ & $\begin{array}{l}\text { marker } \\
\text { bed } M\end{array}$ & $\sim$ base & $\begin{array}{l}\text { marker } \\
\text { bed G }\end{array}$ & $\begin{array}{l}\text { yellowish } \\
\text { bed }\end{array}$ & $\sim$ top & $\sim$ base & $\sim$ top \\
\hline $\begin{array}{l}\mathrm{SiO}_{2} \\
\text { (wt.\%) }\end{array}$ & 47.18 & 47.53 & 47.75 & 47.79 & 47.61 & 47.44 & 47.28 & 47.68 & 47.83 & 46.62 & 47.50 & 47.57 & 48.27 & 47.7 & 47.95 & 47.99 & 47.78 & 48.33 & 47.74 \\
\hline $\mathrm{TiO}_{2}$ & 0.68 & 0.68 & 0.70 & 0.72 & 0.70 & 0.70 & 0.67 & 0.69 & 0.72 & 0.68 & 0.68 & 0.70 & 0.77 & 0.7 & 0.71 & 0.72 & 0.72 & 0.69 & 0.75 \\
\hline $\mathrm{Al}_{2} \mathrm{O}_{3}$ & 16.42 & 15.51 & 15.94 & 16.25 & 16.26 & 15.16 & 15.00 & 15.57 & 16.27 & 15.35 & 15.25 & 16.55 & 16.55 & 15.67 & 16.02 & 16.39 & 15.99 & 16.24 & 16.93 \\
\hline $\mathrm{Fe}_{2} \mathrm{O} 3$ & 11.47 & 11.37 & 11.37 & 10.95 & 11.41 & 10.89 & 10.77 & 11.53 & 11.39 & 10.92 & 11.56 & 11.33 & 11.32 & 11.36 & 11.46 & 10.87 & 11.36 & 11.85 & 11.94 \\
\hline MnO & 0.18 & 0.18 & 0.18 & 0.19 & 0.18 & 0.18 & 0.18 & 0.18 & 0.18 & 0.19 & 0.18 & 0.18 & 0.18 & 0.18 & 0.18 & 0.19 & 0.18 & 0.19 & 0.19 \\
\hline Mgo & 9.06 & 9.50 & 9.04 & 8.41 & 8.75 & 9.38 & 9.66 & 9.45 & 8.44 & 9.60 & 9.67 & 8.63 & 7.91 & 8.82 & 8.92 & 8.15 & 8.59 & 7.91 & 7.12 \\
\hline CaO & 13.98 & 13.97 & 13.75 & 13.86 & 13.88 & 14.22 & 14.39 & 13.66 & 13.67 & 14.62 & 13.85 & 13.82 & 13.31 & 13.69 & 13.72 & 13.71 & 13.42 & 13.49 & 13.14 \\
\hline $\mathrm{Na}_{2} \mathrm{O}$ & 1.60 & 1.60 & 1.71 & 1.55 & 1.75 & 1.42 & 1.27 & 1.68 & 1.77 & 1.44 & 1.46 & 1.80 & 1.78 & 1.62 & 1.72 & 1.56 & 1.73 & 1.66 & 1.73 \\
\hline $\mathrm{K}_{2} \mathrm{O}$ & 0.29 & 0.31 & 0.31 & 0.31 & 0.33 & 0.31 & 0.28 & 0.33 & 0.35 & 0.26 & 0.34 & 0.31 & 0.38 & 0.35 & 0.34 & 0.32 & 0.35 & 0.32 & 0.31 \\
\hline $\mathbf{P}_{2} \mathbf{0 5}$ & 0.10 & 0.11 & 0.11 & 0.11 & 0.11 & 0.10 & 0.10 & 0.11 & 0.11 & 0.09 & 0.10 & 0.10 & 0.12 & 0.12 & 0.11 & 0.11 & 0.14 & 0.11 & 0.11 \\
\hline SUM & 101.15 & 100.94 & 101.05 & 100.30 & 101.16 & 99.96 & 99.77 & 101.10 & 100.92 & 99.92 & 100.78 & 101.18 & 100.77 & 100.41 & 101.33 & 100.15 & 100.46 & 100.96 & 100.15 \\
\hline $\begin{array}{l}\text { Co } \\
\text { (ppm) }\end{array}$ & 51 & 56 & 54 & I & 53 & 1 & l & 55 & 54 & I & 57 & 56 & 52 & 54 & 53 & 1 & 54 & 51 & 53 \\
\hline $\mathrm{Cr}$ & 210 & 284 & 258 & 254 & 220 & 281 & 265 & 258 & 229 & 282 & 236 & 226 & 209 & 244 & 246 & 226 & 245 & 130 & 76 \\
\hline $\mathbf{N i}$ & 77 & 83 & 84 & 61 & 92 & 73 & 74 & 88 & 60 & 78 & 88 & 66 & 60 & 78 & 80 & 58 & 68 & 36 & 36 \\
\hline Sr & 407 & 384 & 396 & 396 & 404 & 373 & 371 & 386 & 400 & 384 & 382 & 409 & 405 & 391 & 398 & 400 & 395 & 437 & 463 \\
\hline Ba & 226 & 233 & 237 & 302 & 232 & 251 & 239 & 261 & 274 & 212 & 252 & 245 & 278 & 289 & 257 & 272 & 265 & 208 & 202 \\
\hline $\mathrm{Zr}$ & 36 & 35 & 38 & 39 & 38 & 35 & 34 & 39 & 41 & 35 & 33 & 37 & 41 & 40 & 39 & 39 & 39 & 38 & 39 \\
\hline $\mathbf{R b}$ & 7 & 5 & 5 & 12 & 8 & 8 & 8 & 8 & 8 & 11 & 8 & 5 & 7 & 6 & 8 & 9 & 8 & 9 & 8 \\
\hline $\mathrm{Zn}$ & 65 & 67 & 67 & 75 & 68 & 72 & 73 & 69 & 68 & 72 & 70 & 63 & 72 & 66 & 67 & 77 & 72 & 73 & 78 \\
\hline v & 298 & 295 & 300 & 1 & 299 & 1 & 1 & 302 & 307 & 1 & 292 & 299 & 292 & 290 & 302 & 1 & 288 & 326 & 324 \\
\hline $\mathbf{Y}$ & 17 & 18 & 16 & 13 & 16 & 15 & 15 & 16 & 16 & 13 & 19 & 18 & 18 & 19 & 16 & 14 & 15 & 11 & 17 \\
\hline
\end{tabular}



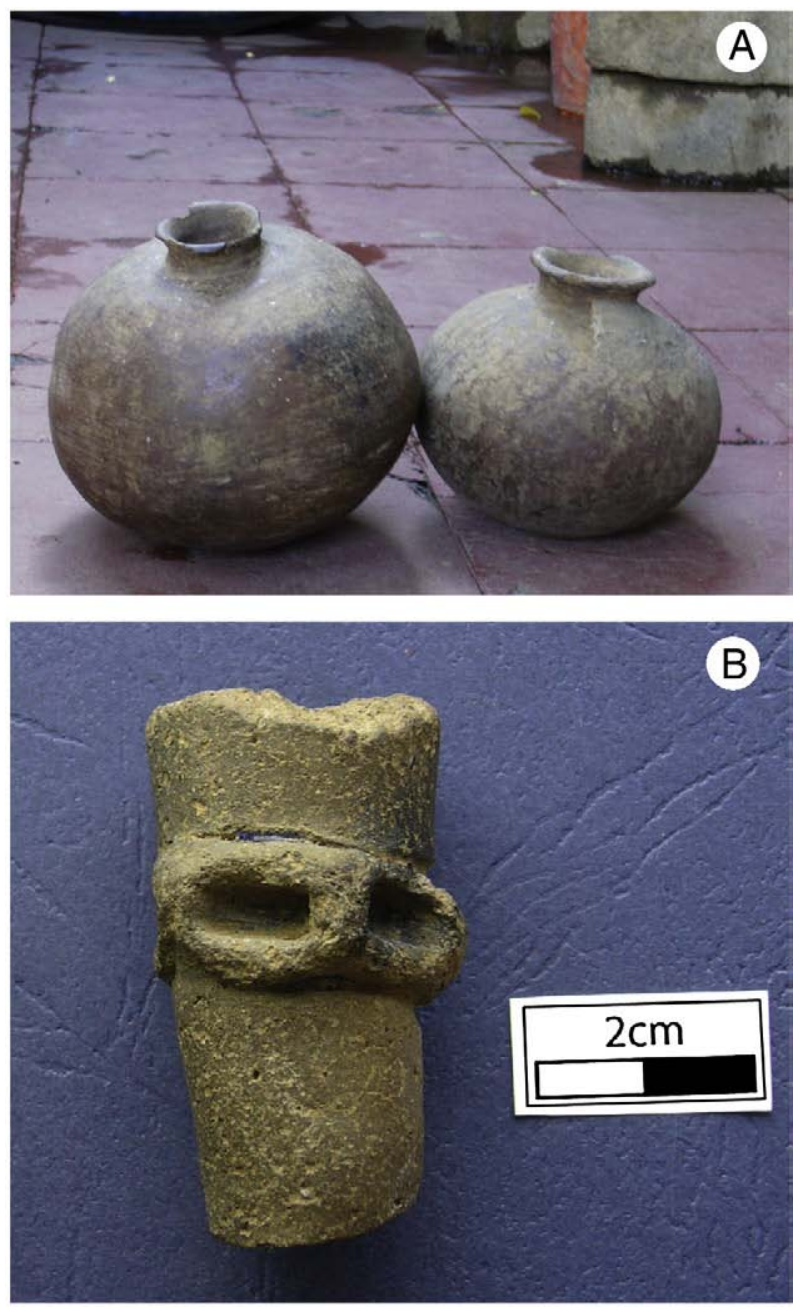

Fig. 15. (A) Ceramic mastered by the Usulután negative technique between 2.7 and $1.7 \mathrm{ka} \mathrm{BP}$, found in paleosol underlying NT and (B) Ometepe ceramic mastered in Mesoamerica between 650 and 450 a BP, found in soil overlying NT.

Vesicles in both deposits are commonly more regular in lapilli of lower layers and become irregular towards the uppermost layers. Vesicularity within the lapilli of the southern deposits varies widely (55-70 vol.\%). The modal percentage of vesicles increases significantly upward from 20 to 70 vol.\% in S deposits and from 30 to 40 vol.\% in W/NW deposits.

\section{Chemical composition}

NT basalts are moderately mafic tholeiite as shown by 19 XRF whole rock major and trace element analyses (Figs.13A,B and 14; Table 3). $\mathrm{MgO}$ (7.11-9.68 wt.\%), $\mathrm{Al}_{2} \mathrm{O}_{3}$ (15.03-16.90 wt.\%), and $\mathrm{CaO}$ (13.12-14.63 wt.\%) concentrations are moderately high while $\mathrm{TiO}_{2}$ (0.67-0.76 wt.\%), $\mathrm{K}_{2} \mathrm{O}$ (0.26-0.38 wt.\%), Ba (202-302 ppm) and $\mathrm{Sr}$ (371-463 ppm) are low. Two compositional groups of Nejapa basalts can be clearly distinguished from each other geochemically by their major and trace element concentrations (Fig. 14; Table 3).

\subsection{Southern Group (SG) and Western/Northwestern Group (W/NWG)}

The basalts exposed W/NW of Nejapa Maar are characterized by higher $\mathrm{MgO}$ (8.14-9.68 wt.\%) and $\mathrm{CaO}$ (13.21-14.63 wt.\%) compared to the southern group (Fig. 14) while SiO2 (46.64-47.92 wt.\%) and $\mathrm{FeO}^{\mathrm{T}}$ (9.70-10.32 wt.\%) concentrations are lower. $\mathrm{TiO}_{2}$ is low (0.67$0.76 \mathrm{wt} . \%$ ) and indistinguishable from its concentration in the southern pyroclastics. $\mathrm{Al}_{2} \mathrm{O}_{3}$ is slightly lower in the $\mathrm{W} / \mathrm{NWG}$ varying from 15.03 to $16.42 \mathrm{wt} . \%$. Total alkalis $\left(\mathrm{NaO}_{2}+\mathrm{K}_{2} \mathrm{O}\right)$ are low in both the W/NWG (1.55-2.15 wt.\%) and the SG (1.96-2.04 wt.\%). Compatible trace elements $\mathrm{Cr}$ (209-284 ppm) and Ni (58-92 ppm) are higher in the W/NW pyroclastics, while semi-compatible trace element $\mathrm{Sr}$ (371-409 ppm) is lower and $\mathrm{Ba}(212-302 \mathrm{ppm})$ is higher than in the SG. V (324-326 ppm) and Zn (73-78 ppm) are higher in the southern pyroclastics (Fig. 14; Table 3).

\section{Discussion}

\subsection{Comparison between $S G$ and $W / N W G$}

Juveniles from the southern and western/northwestern lobes of NT differ significantly from each other compositionally. Whole rock compositions of the southern group are distinguished by higher $\mathrm{SiO} 2$, $\mathrm{FeO}^{\mathrm{T}}, \mathrm{Al}_{2} \mathrm{O}_{3}, \mathrm{MnO}, \mathrm{V}, \mathrm{Zn}$ and $\mathrm{Sr}$ and lower $\mathrm{MgO}, \mathrm{CaO}, \mathrm{Cr}$ and Ni from the $\mathrm{W} / \mathrm{NWG}$, representing a slightly more evolved magma. The southern facies deposits represent a classical opening phase of a hydroclastic Maar eruption as illustrated by their poor sorting, abundance of lithoclasts and the enormous size of some blocks. Moreover, and similar to many scoria cones in the Eifel, slightly more evolved magmas are erupted first, reflecting successive top-down eruption from a slightly compositionally zoned magma reservoir (Schmincke, 2007). Similarly, NT magmas of the later and bulk deposits of the western/northwestern lobes are slightly more primitive compared to magmas of the southern lobe interpreted to have erupted during the opening phase.

\section{Previous geochemical studies}

Ui (1972), Walker (1984), Walker et al. (1990, 2001) and Carr et al. (2004) recognized that the deposits of the Nejapa and Granada cinder cone alignments are basaltic in composition and called them Nejapa-Granada (NG) group. Walker (1984) and Walker et al. (1990) divided the NG-basalts into 3 groups based on contrasting $\mathrm{TiO}_{2}-\mathrm{K}_{2} \mathrm{O}$ concentrations: (1) low-Ti ( $\left.<1 \mathrm{wt} . \%\right)$ basalts with high $\mathrm{K}_{2} \mathrm{O}$, Ba and $\mathrm{Rb}$ and usually low $\mathrm{Ni}$ and $\mathrm{Cr}$; (2) high-Ti (>1 wt.\%) basalts with opposite element concentrations; and (3) hybrid basalts with intermediate compositions, possibly representing magma-mixing.

Here, we have focused only on one volcanic center (Nejapa Maar) with two goals: (1) determination of compositional variations within the Nejapa magma (Fig. 14) and (2) comparison of the newly defined Nejapa magma type with previously analyzed rocks of the NML (Fig. 13B). All NT compositions are low-Ti basalts showing some typical characteristics of the low-Ti group of Walker (1984) and Walker et al. (1990), such as higher $\mathrm{K}_{2} \mathrm{O}$ (Fig. 13B), Ba, $\mathrm{Rb}$ and $\mathrm{Sr}$ and usually lower $\mathrm{Ni}$ and $\mathrm{Cr}$ than the high-Ti group. Nevertheless, the $\mathrm{TiO}_{2}, \mathrm{~K}_{2} \mathrm{O}, \mathrm{Ba}, \mathrm{Rb}$ and $\mathrm{Sr}$ concentrations of the NT are slightly lower than the low-Ti average concentrations presented by Walker, possibly indicating slightly smaller contributions from the slab (Rausch and Schmincke 2008). Pardo et al. (2009) presented 10 major element chemical analyses that clearly show 2 different groups of basalts in the TAS diagram (Fig. 13A). Five samples have higher alkali concentrations ( $\sim$ wt.\%) with low $\mathrm{MgO}$ concentrations ( $\sim-6 \mathrm{wt} . \%)$ that chemically correspond to Asososca member proper (unpublished analyses of Freundt et al.), while five samples have $<2$ wt. $\% \mathrm{Na}_{2} \mathrm{O}+\mathrm{K}_{2} \mathrm{O}$ concentrations with relatively high $\mathrm{MgO}$ (7-9.5 wt.\%), the latter resembling our NT compositions (Fig. 13A). In addition, $\sim 7$ samples are high-Ti basalts while $\sim 3$ samples are low-Ti basalts. Probably some of these basalts constitute a third group with intermediate compositions (Fig. 13B). This compositional heterogeneity also shows that Pardo et al. (2009) apparently combined samples of at least two different 


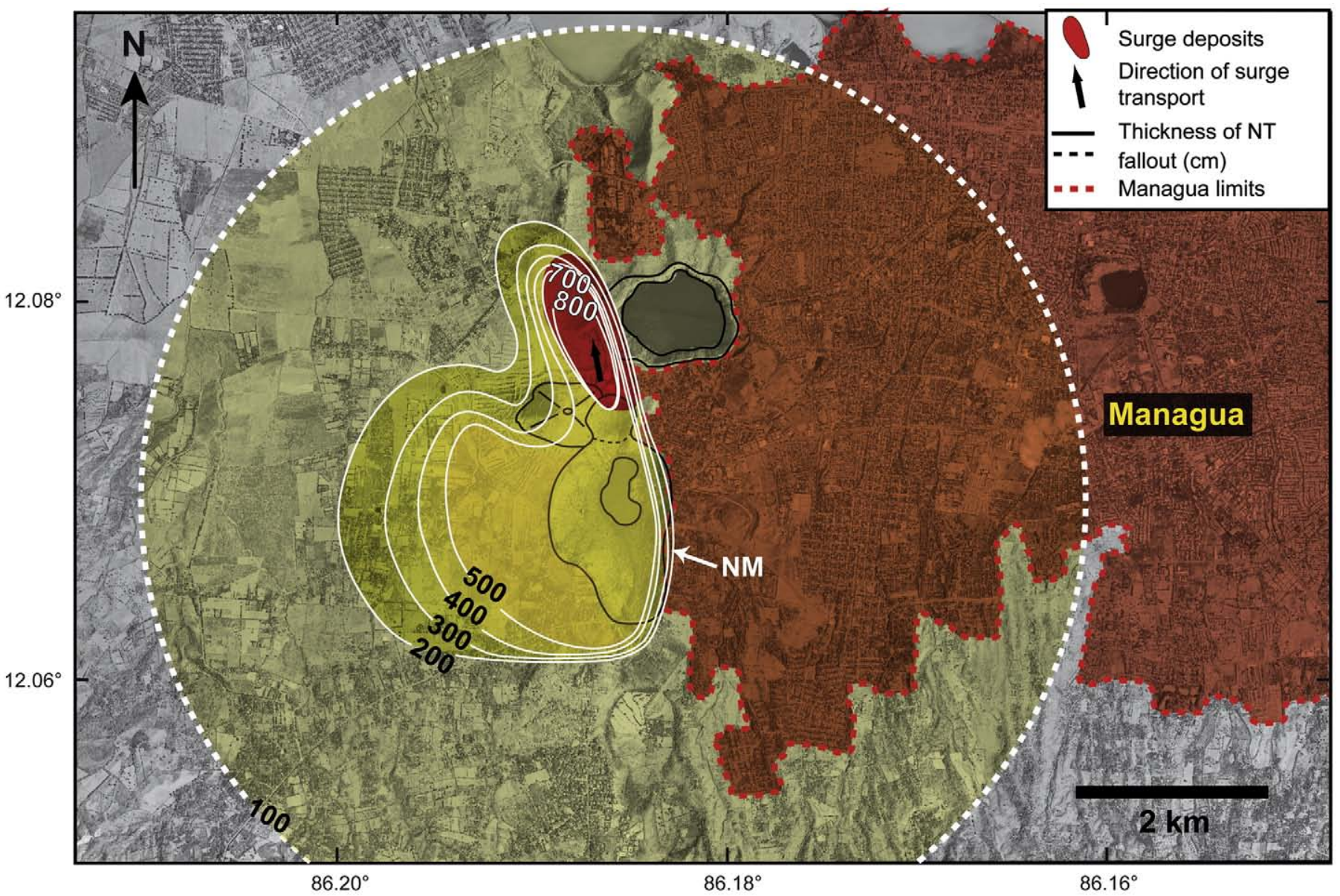

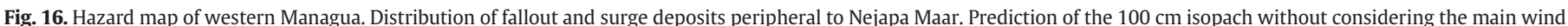
direction.

lithostratigraphic units, the c. 6 ka old Asososca and the c. 1 ka old Nejapa Tephras.

\section{Age of Nejapa eruption}

Orange/brownish ceramic sherds with imprints of wavy, yellowish lines related to the Usulután negative lost wax technique, produced in Mesoamerica during the Late Formative Period (2.71.7 ka BP) (García, 2006) were found by us in the paleosol between Masaya Tuff (MT) and Nejapa Tephra (NT) (Fig. 15A). The Usulután ceramics seem to have been produced mainly in Honduras and Chalchuapa, a Maya site of western El Salvador. The indigenous groups of Mesoamerica are known as traders and exchangers, which would explain how these ceramics came to Nicaragua. Since the MT is approximately $1.8 \mathrm{ka}$ BP old (Kutterolf, et al., 2007), the NT may be appreciably younger because the underlying MT is deeply weathered. NT is topped by a soil which contains pottery sherds from the Ometepe ceramic technique, mastered in Mesoamerica between 650 and 450 a BP (García, 2006) (Fig. 15B). The Ometepe people disappeared with the Spanish invasion. The lack of historical records written by the Spanish conquistadores regarding volcanic events in Nicaragua at this time suggests - but does not prove that Nejapa Maar erupted prior to the Spanish invasion (500 a BP). The development of a regional paleosol between the MT and NT combined with the period of production of the upper and lower pottery suggest an age between 1.2 and $0.7 \mathrm{ka}$ BP. Pardo et al. (2008) bracketed the Nejapa Tephra deposit (which they interpreted to have been erupted from Asososca Maar) as between $1245 \pm 125$ a BP and $535 \pm 110$ a BP (radiocarbon dates of bracketing paleosols), practically identical to our age estimate based on pottery.

\section{Volcanic hazards and risks}

Western central Nicaragua dotted with many highly explosive active volcanic centers (e.g. Masaya Caldera, Apoyo Caldera, Chiltepe Volcanic Complex and Nejapa-Miraflores Lineament) is exposed to various types of volcanic eruptions occurring at high frequencies.

The vulnerability of the densely populated area (Managua (c. 1.300000), Masaya (140000), Ciudad Sandino (130000) and Granada (110000), all growing at high rates) and thus the risk from major volcanic eruptions are extreme. Managua is built on many volcanic deposits produced mostly by explosive moderate-magnitude eruptions (VEI up to 5) during the past few ten thousand years. Moreover, Managua lies in a particularly active tectonic zone where disastrous historical earthquakes, e.g. the 1931 and 1972 earthquakes, caused massive destruction and more than 13000 fatalities (La Femina et al., 2002).

Several types of volcanic hazards characterized the evolution of the eruption of Nejapa Maar (see below), all posing major volcanic risks for western Managua and Ciudad Sandino (Fig. 16). Although the magma volume erupted at Nejapa Maar is relatively small $\left(\sim 0.1 \mathrm{~km}^{3}\right)$, the fact that Nejapa Maar lies within the densely populated western districts (barrios) of Managua and in view of continued rapid expansion westwards, volcanic risk assessment is extremely important. 


\subsection{Fallout deposits}

Ballistic transport of blocks up to $1 \mathrm{~m}$ in diameter, dominantly during the highly explosive phreatomagmatic opening phase of the Nejapa eruption, represents a major hazard for buildings and people at distances at least $1 \mathrm{~km}$ from Nejapa Maar. Blocks up to $3.5 \mathrm{~m}$ in diameter concentrated along the rim of Nejapa Maar, particularly on the densely populated southern and eastern Nejapa rim, would completely destroy a belt about $500-\mathrm{m}$ wide peripheral to Nejapa Maar. At larger distances, ash and lapilli fallout deposits would cause roof collapse due to the heavy load of rapidly accumulated tephra. Low-quality roofs, common in Nicaragua, probably collapse at a load pressure as low as $>1 \mathrm{kPa}$ equivalent to $10 \mathrm{~cm}$ of basaltic tephra (Pyle, 2000). Because of the exponential decay rule of fallout deposits (Pyle, 1989), NT may still be $10 \mathrm{~cm}$ thick at a distance of approx. $12 \mathrm{~km}$. Thus, a recurrence of a Nejapa-type eruption with similar magnitude and eruptive and transport mechanisms can cause some roof collapse up to $12 \mathrm{~km}$ peripheral to Nejapa Maar (Fig. 16).

Tephra fallout can also cause disruption of water supplies (Asososca Maar e.g., only $1 \mathrm{~km}$ from Nejapa Maar, is the main water reservoir for Managua), can damage agricultural products and cattle, as well as mechanical systems (e.g. vehicles, aircraft engines). Moreover, respiratory ailments (e.g. asthma) are a common hazard during explosive volcanic eruptions.

\subsection{Surge deposits}

Surges are concentrated in the northern lobe within the Managua Graben and are considered a major hazard over proximal and medial distances due to their velocity and energy and, in some cases, elevated temperature (Schmincke, 2004). Buildings and plantations can be rapidly destroyed and people do not normally have enough time to escape. Surges were not common during the Nejapa eruption, thus volcanic hazards were less controlled by surge transport than by fallout. Nevertheless, surge transport of higher energy and temperature cannot be excluded during a future eruption.

\subsection{Vulnerability and risk in the study area}

The probability of damage in Managua and Ciudad Sandino by volcanic eruptions is extremely high, because of the proximity to the NML-zone, the high population density of the area and concentration of agriculture and economic centers. Moreover, the quality of infrastructure and the stage of preparedness in Managua, and in Nicaragua in general, is low. According to the last housing census in Nicaragua during 1995 (INEC, 1997a,b), 51 to $72 \%$ of the houses in the study area have zinc-sheet roofs, 7 to $21 \%$ fiber-reinforced cement, 4 to $36 \%$ clay or cement tiles, and 2 to $7 \%$ thatch or waste material. Based on data of the Pinatubo eruption of 1991, all the above-mentioned materials would probably not withstand a few tens of $\mathrm{cm}$ of fallout tephra (Spence et al., 1996). Moreover, the Interamerican Highway that connects Nicaragua with Costa Rica to the south and Honduras to the north, energy supply companies, factories, a nearby oil refinery etc, would be partially if not completely destroyed. In particular, disruption of the above-mentioned oil refinery even by minor volcanic activity might have tremendous environmental implications (e.g. ruin the city's primary water supply: Asososca Maar). The water reservoir of Asososca Maar can also be contaminated by tephra fallout.

Fortunately, many volcanic eruptions are heralded by several types of precursors, especially earthquakes. A modern seismic network is operated in Nicaragua by INETER. What is needed, however, is the development of a modern and effective disaster mitigation management including long-term information of the population and land planning. Over the last 6000 years, major explosive eruptions have hit the Managua area roughly every 1000 years (Kutterolf et al., 2007), this statement having been made prior to the present detailed study and dating of the Nejapa eruption. Based on this evaluation, another major eruption is due soon.

\section{Evolution of Nejapa eruption}

About 1000 years ago, the ground of the Nejapa-Asososca area was densely vegetated by low bushes rooted in the thick paleosol that had developed on the c. $1.8 \mathrm{ka}$ BP Masaya Tuff (MT). The paleosol locally contains strange round rocks 5 to $15 \mathrm{~cm}$ in diameter that appear to be stone tools transported by people because they could not be related to nearby volcanic rocks of the area and a higher ground made of hard rock is missing. Moreover, the paleosol also contains ceramic sherds from Usulután negative technique mastered between 2.7 and $1.7 \mathrm{ka}$ BP. This archaeological discovery and the rocks mentioned are clear evidence that an indigenous population inhabited the Nejapa area at the time of the eruption, the area having been inhabited for some time as shown by the famous footprints at Acahualinca (Schmincke et al., 2009a,b). The site of Nejapa Maar was likely a morphological depression formed by graben collapse and was probably water-filled. Asososca Maar already existed having been formed by a hydroclastic eruption probably $>6$ ka earlier. Nejapa eruption started with a highly explosive initial phreatomagmatic phase with abundant country rocks (up to $40 \mathrm{vol} . \%$ ) deposited at least in the southern rim of Nejapa Maar (up to $6 \mathrm{~m}$ thick). During this opening phase, large boulders up to $3.5 \mathrm{~m}$ in diameter were ejected with high energy towards the northern and western rim of Nejapa Maar. The initial phase was not only powerful, it was also characterized by layers containing vesicular basaltic lapilli not found in the main western and northern lobes suggesting that entirely or dominantly pyroclastic phases apparently alternated with phreatomagmatic pulses during the early stages of Nejapa Maar eruption. We cannot exclude, however, that this facies was also deposited along the northern Maar rim but it was impossible to verify due to thick vegetation. North of Nejapa Maar (up to $1 \mathrm{~km}$ from the vent), a proximal, relatively coarse-grained and lithoclast-rich (up to $1 \mathrm{~m}$ in diameter) facies was deposited, also representing a proximal facies of the NT, which could not be correlated with the southern deposits because of lack of outcrops. The small crater area deduced from a morphological pit and recognition of a distinct northern facies suggests that magma rose along a fissure to form a major crater to the south (Nejapa Maar) and a smaller one $100 \mathrm{~m}$ to the north.

The typically cauliflower-shaped lapilli of the northern and especially the western facies and their fine-grained crusts suggest rapid cooling, likely caused by water (steam) (Fig. 12). Nevertheless, the paucity of glass clearly indicates that the amount of water (steam) responsible for the fast cooling was low, much lower than in classic hyaloclastite tephra rings where juvenile clasts dominantly consist of sideromelane. The slight to moderate vesicularity (20-40 vol.\% generally but up to 70 vol.\%) of the NT indicates retarded fragmentation of a vesiculating magma. Thus, degassing, vesiculation and beginning of pyroclastic fragmentation during magma rise preceded magma/water interaction at low pressure. Moreover, the paucity of fine-grained tephra contrasts strongly with many maar deposits suggesting that hydroclastic fragmentation was on a small scale and, moreover, that the deposits were laid down basically dry or damp and cool or warm, but not hot. Most eruptions in Nejapa Maar following the initial phase, principally deposited west and northwest of Nejapa Maar, do not fit easily into either hydroclastic or strombolian eruptions. For one, crater enlargement appears to have occurred mainly at the beginning, because lithoclasts are minor throughout most of the eruption. The other reasons are believed to be due to a limited water supply and a rather shallow level at which rising and vesiculating magma that started to become fragmented interacted with limited amounts of water. On the other hand, the well-bedded character of the 
NT strongly resembles the structures typical of maar deposits (Schmincke, 2004). Such layering clearly reflects rhythmic eruptions caused by at least 200 individual explosive pulses, the driving force and energy for the eruption columns probably being a combination of expanding steam and magmatic gas.

Since the contact between each layer is sharp without any signs of erosion, explosive pulses followed each other fairly quickly, suggesting that the Nejapa Maar eruption took place probably during only a few days or weeks or at most a few months, a major aspect to be considered in any risk assessment.

NT was dominantly transported as fallout influenced strongly by wind conditions at the time of eruption. The eruption column likely reached up to $5-7 \mathrm{~km}$ in the troposphere where it bent to the west and northwest due to the dominant winds at this time. Surge transport is concentrated in the northern lobe mainly being channelled by the topography and filling the pre-existent morphological depression of the Managua Graben. This explains the fact that NT is particularly thick in the northern lobe. In general, fine-grained $\left(\operatorname{Md}_{\varnothing}>1\right)$ poorly-sorted $\left(\sigma_{\varnothing}>2\right)$ and locally duned layers are thought to have been deposited by (largely dry) surges. Dominantly coarser grained $\left(\mathrm{Md}_{\varnothing}=0\right.$ to -2$)$ well to moderately sorted layers are interpreted as fallout deposits. The marker horizons $A, G$ and $M$, well correlated in the western and northwestern lobes, are interpreted as fallout because of their relatively widespread distribution, good to moderate sorting and exponential decrease in thickness away from Nejapa Maar (Figs. 9A,B, 10). Each of these must have resulted from especially powerful explosive events.

The length of the time interval between the NT eruption and resettlement of the area cannot be estimated. No remains of people living around Nejapa Maar were found. However, the base of the deposit is not widely exposed in the area proximal to the crater. This is not unusual because people tend to leave areas of potential future volcanic eruptions because of powerful precursors (e.g. AkrotiriSantorini, Pompeii, Laacher See, etc). Moreover, it may have taken tens if not hundreds of years before the area became resettled. Nevertheless, the proximity to Lago de Managua but also to Asososca Maar, which represents the main reservoir of drinking water in Managua, has always attracted people to settle. Nejapa Maar itself may have been a convenient place for washing in the warm water $\left(41^{\circ} \mathrm{C}\right)$, as noted by McBirney (1956) and its sulphurous waters are even today considered by many residents to have medicinal properties.

\section{Conclusions}

1. The newly defined Nejapa Tephra (NT), sourced in Nejapa Maar located within the 15-km-long, N-S-trending volcano-tectonic Nejapa-Miraflores Lineament (NML), represents the youngest (0.7-1.2 ka BP) known tephra deposit in western Managua, Nicaragua. The tephra deposits described by us cannot have been erupted in Asososca Maar as postulated by Pardo et al. (2008, 2009). For one, isopach and isopleth maps unequivocally indicate Nejapa Maar as the central vent. Moreover, up to 8-m thick medialto fine-grained deposits about $200 \mathrm{~m}$ west of the rim of Asososca Maar represent a medial facies of NT.

2. Nejapa Tephra is interpreted to have been fragmented by shallow interaction of a vesiculating magma with limited amounts of water resulting in a highly explosive mixed hydroclastic/pyroclastic eruption.

3. Dominant transport mechanism was fallout from moderately high eruption columns $(7-10 \mathrm{~km})$, while surge and ballistic transport was minor. Specific fallout layers were correlated throughout the entire study area and used as marker horizons. Surge deposits are concentrated north of Nejapa Maar in a morphological/tectonic depression identified as the western part of the Managua Graben. Thus, Managua Graben formation preceded the eruption of Nejapa
Tephra. Ballistic transport was concentrated along the southern and eastern rim of Nejapa Maar.

4. Three depositional lobes were recognized: (1) a southern lobe with a coarse-grained, lithoclast-rich deposit limited to a few tens of meters from the rim of Nejapa Maar, which is interpreted by us as the opening phase of the phreatomagmatic Nejapa eruption; (2) a semi-concentric western lobe characterized by well-bedded juvenile lapilli ( $>90$ vol.\%) layers erupted during the main eruption making up the bulk of the deposit; and (3) an elongated northern lobe with a proximal coarse-grained, lithoclast-rich facies of the Nejapa Tephra that could not be correlated with the southern deposits because of lack of outcrops. The medial/distal facies of the northern lobe is interpreted as a transitional deposit to the western lobe.

5. Nejapa Tephra compositions are moderately mafic tholeiitic basalts characterized by high Mg and Ca and low Ti concentrations. Nejapa basalts, as most NML basalts, are relatively primitive compared to CAVA basalts. Nejapa basalts can be compositionally subdivided into a southern more evolved and a western/northwestern slightly more primitive group.

6. Although the minimum total volume of erupted Nejapa Tephra is small $\left(0.09 \mathrm{~km}^{3}\right)$, the recurrence of an eruption of the same magnitude at Nejapa Maar or another close-by eruptive vent and similar eruptive and transport mechanisms would be a major hazard and risk to western Managua and Ciudad Sandino, due to the fact that Nejapa Maar lies within Managua, the extremely vulnerable, most densely populated city of Nicaragua. Specific hazards include dominantly fallout deposits destroying roofs up to at least $12 \mathrm{~km}$ peripheral to Nejapa Maar, surge deposits filling morphological depressions, and ballistic impacts damaging buildings at distances at least as far as $1 \mathrm{~km}$ from Nejapa Maar.

\section{Acknowledgments}

This publication is contribution No. 180 of the Sonderforschungsbereich (SFB) 574 "Volatiles and Fluids in Subduction Zones" at Kiel University (Germany). Field work was supported financially by the Deutscher Akademischer Austauschdienst (DAAD) and SFB 574 for JR and Deutsche Forschungsgemeinschaft (DFG) for HUS. Logistic support during the field work was provided by the Instituto Nicaragüense de Estudios Territoriales (INETER) in Managua. We thank Armin Freundt, Chuck Connor and an anonymous reviewer for critical comments that helped to improve the manuscript.

\section{References}

Bednarz, U., Schmincke, H.-U., 1990. Evolution of the Quaternary melilite-nephelinite Herchenberg volcano (East Eifel). Bull. Volcanol. 52, 426-444.

Bice, D.C., 1985. Quaternary volcanic stratigraphy of Managua, Nicaragua: correlation and source assignment for multiple overlapping plinian deposits. Geol. Soc. Amer. Bull. 96, 553-566.

Carey, S., Sparks, R.S.J., 1986. Quantitative models of the fallout and dispersal of tephra from volcanic eruption columns. Bull. Volcanol. 48, 109-125.

Carr, M.J., Feigenson, M.D., Patino, L.C., Walker, J.A., 2004. Volcanism and geochemistry in Central America: progress and problems. In: Eiler, J. (Ed.), Inside the Subduction Factory: Geophys. Monogr. Ser., 138, pp. 153-174.

De Mets, C., 2001. A new estimate for present-day Cocos-Caribbean plate motion: implications for slip along the Central American volcanic arc. Geophys. Res. Lett. 28, 4043-4046.

Fierstein, J., Nathenson, M., 1992. Another look at the calculation of fallout tephra volumes. Bull. Volcanol. 54, 156-167.

Freundt, A., Kutterolf, S., Wehrmann, H., Schmincke, H.-U., Strauch, W., 2006a. Eruption of the dacite to andesite zoned Mateare Tephra, and associated tsunamis in Lake Managua, Nicaragua. J. Volcanol. Geotherm. Res. 149, 103-123.

Freundt, A., Kutterolf, S., Schmincke, H.-U., Hansteen, T.H., Wehrmann, H., Pérez, W., Strauch, W., Navarro, M., 2006b. Volcanic hazards in Nicaragua: past, present, and future. In: Rose, W.I., Bluth, G.J.S., Carr, M.J., Ewert, J., Patino, L.C., Vallance, J.W. (Eds.), Volcanic Hazards in Central America: Geol. Soc. Am. Spec. Publ. , pp. $141-165$.

Freundt, A., Hartmann, A., Kutterolf, S., Strauch, W., 2009. Volcaniclastic stratigraphy of the Tiscapa maar crater walls (Managua, Nicaragua): implications for volcanic and 
seismic hazards and Holocene climate changes. Int. J. Earth. Sci.. doi10.1007/ s00531-009-0469-6

Frischbutter, A., 2002. Structure of the Managua Graben, Nicaragua, from remote sensing images. Geofis. Intern. 41, 87-102.

García, R., 2006. Pers. comm.

INEC (Instituto Nacional de Estadísticas y Censos), 1997a. VII Censo Nacional de Población y III de Vivienda 1995, Vivienda, Municipios, v. II.

INEC (Instituto Nacional de Estadísticas y Censos), 1997b. VII Censo Nacional de Población y III de Vivienda 1995, Población, Municipios, v. IV.

Krusi, A., Schultz, J., 1979. Base surge deposits of the Nicaragua volcano Masaya. Geol. Soc. Amer. Abstr. Progr. 11, 87-88.

Kutterolf, S., Freundt, A., Pérez, W., Wehrmann, H., Schmincke, H.-U., 2007. Late Pleistocene to Holocene temporal succession and magnitudes of highly-explosive volcanic eruptions in west-central Nicaragua. J. Volcanol. Geotherm. Res. 163, 55-82.

Kutterolf, S., Freundt, A., Pérez, W., Mörz, T., Schacht, U., Wehrmann, H., Schmincke, H.-U., 2008. The Pacific offshore record of Plinian arc volcanism in Central America I: along-arc correlations. Geochem. Geophys. Geosyst. 9. doi10.1029/ 2007 GC001631.

La Femina, P.C., Dixon, T.H., Strauch, W., 2002. Bookshelf faulting in Nicaragua. Geology $30,751-754$

McBirney, A.R., 1956. The origin of the Nejapa Pits near Managua, Nicaragua. Bull. Volcanol. 17, 145-154.

McBirney, A.R., Williams, H., 1964. The origin of the Nicaragua depression. Bull. Volcanol. 27, 65.

McBirney, A.R., Williams, H., 1965. Volcanic History of Nicaragua. Univ. Calif. Publ. Geol. Sci, Berkeley. 65 pp.

NOAA-CIRES (Climate Diagnostics center), 2001. Data provided from NCEP wind data. Boulder, Colorado http://www.cdc.noaa.gov/cgi-bin/DataMenus.pl? dataset $=$ NCEP.

Pardo, N., Avellán, D.R., Macías, J.L., Scolamacchia, T., Rodriguez, D., 2008. The $\sim 1245$ yr BP Asososca maar: new advances on recent volcanic stratigraphy of Managua (Nicaragua) and hazard implications. J. Volcanol. Geotherm. Res. 176, 493-512.

Pardo, N., Macías, J.L., Giordano, G., Cianfarra, P., Avellán, D.R., Bellatreccia, F., 2009. The $\sim 1245$ yr BP Asososca maar eruption: The youngest event along the NejapaMiraflores volcanic fault, Western Managua, Nicaragua. J. Volcanol. Geotherm. Res. 184, 292-312.

Pérez, W., Freundt, A., 2006. The youngest highly explosive basaltic eruptions from Masaya Caldera (Nicaragua): stratigraphy and hazard assessment. In: Rose, W.I., Bluth, G.J.S., Carr, M.J., Ewert, J., Patino, L.C., Vallance, J.W. (Eds.), Volcanic Hazards in Central America: Geol. Soc. Am. Spec. Publ. , pp. 189-207.

Pérez, W., 2007. Basaltic Plinian and violent Surtseyan eruptions from the Masaya Caldera Complex, Nicaragua. PhD thesis, 1-192.

Pérez, W., Freundt, A., Kutterolf, S., Schmincke, H.-U., 2009. The Masaya Triple Layer: a 2100 year old basaltic multi-episodic Plinian eruption from the Masaya Caldera Complex (Nicaragua). J. Volcanol. Geotherm. Res. 179, 191-205.

Pyle, D.M., 1989. The thickness, volume and grain size of tephra fall deposits. Bull. Volcanol. 51, 1-15.

Pyle, D.M., 2000. Sizes of volcanic eruptions. In: Sigurdsson, H., Houghton, B., McNutt, S., Rymer, H., Stix, J. (Eds.), Encyclopedia of Volcanoes. Academic Press, pp. 263-269.
Rausch, J., Schmincke, H.-U., 2007. A Prehistoric (c. 1 ka BP) Large Volume $\left(>1 \mathrm{~km}^{3}\right.$ DRE) Hydroclastic Basaltic-andesitic Eruption Sourced in Nejapa Maar (Managua, Nicaragua). Abstract. LAK 2007, p. 275. http://www.lak2007.uni-kiel.de/.

Rausch, J., Schmincke, H.-U., 2008. Nejapa Tephra: The Youngest (c. 1 ka BP) Highly Explosive Hydroclastic Basaltic Eruption in Western Managua (Nicaragua). Shaker Verlag. $72 \mathrm{pp}$.

Schmincke, H.-U., 2004. Volcanism. Springer Verlag, Berlin, pp. 1-324.

Schmincke, H.U., 2007. The Quaternary volcanic fields of the East and West Eifel (Germany). In: Ritter, R., Christensen, U. (Eds.), Mantle Plumes-A Multidisciplinary Approach. Springer, Heidelberg, pp. 241-322.

Schmincke, H.-U, Kutterolf, S, Pérez, W Rausch, J., Freundt, A, Strauch, W, 2009a. Walking through volcanic mud: the 2,100 year-old Acahualinca footprints (Nicaragua) I: stratigraphy, lithology, volcanology and age of the Acahualinca section. Bull. Volcanol. 71, 479-493.

Schmincke, H.-U., Rausch, J., Kutterolf, S., Freundt, A., 2009b. Walking through volcanic mud: the 2.100 year-old Acahualinca footprints (Nicaragua) II: the Acahualinca people, environmental conditions and motivation. Int. J. Earth. Sci. doi10.1007/ s00531-009-0438-0.

Spence, R.J.S., Pomonis, A., Baxter, P.J., Coburn, A.W., White, M., Dayrit, M., 1996. Building damage caused by the Mount Pinatubo eruption of June 15, 1991. In: Newhall, C.G., Punongbayan, R.S. (Eds.), Fire and Mud: Eruptions and Lahars of Mount Pinatubo, Philippines. University of Washington Press, Seattle, pp. 1055-1062.

Ui, T., 1972. Recent volcanism in the Masaya-Granada area, Nicaragua. Bull. Volcanol. 36, 174-190.

van Wyk de Vries, B., 1993. Tectonics and magma evolution of Nicaraguan volcanic systems. Unpub. Ph.D. Thesis, Open University, Milton Keynes, UK, pp. 1-328.

Walker, G.P.L., 1971. Grain-size characteristics of pyroclastic deposits. J. Geol. 79, 696-714.

Walker, J.A., 1984. Volcanic rocks from the Nejapa and Granada cinder cone alignments, Nicaragua, Central America. J. Petrology 25, 299-342.

Walker, J.A., Carr, M.J., Feigenson, M.D., Kalamarides, R.I., 1990. The petrogenetic significance of interstratified high- and low-Ti basalts in Central America. J. Petrology 31, 1141-1164.

Walker, J.A., Patino, L.C., Carr, M.J., Feigenson, M.D., 2001. Slab control over HFSE depletions in Central Nicaragua. Earth Planet. Sci. Lett. 192, 533-543.

Wehrmann, H., Bonadonna, C., Freundt, A., Houghton, B.F., Kutterolf, S., 2006. Fontana Tephra: a basaltic plinian eruption in Nicaragua. In: Rose, W.I., Bluth, G.J.S., Carr, M. J., Ewert, J., Patino, L.C., Vallance, J.W. (Eds.), Volcanic Hazards in Central America: Geol. Soc. Am. Spec. Publ. , pp. 209-223.

Weiss, M., 2004. Recent volcanic history of western Managua, Nicaragua-risk assessment. Unpub. M.A. Thesis (Diplomkartierung), Christian-Albrechts-Universität zu Kiel.

Weyl, R., 1980. Geology of Central America, In: Bender, F. (Ed.), Beiträge zur Regionalen Geologie der Erde, 2nd Ed. Gebr. Borntraeger, Berlin-Stuttgart, pp. 1-371.

Williams, H., 1952. Geologic observations on the ancient human footprints near Managua, Nicaragua. Carnegie. Inst. Wash. Pub. (Contrib Amer Anth Hist 11) 596: $1-32$.

Williams, S.N., 1983. Geology and eruptive mechanisms of Masaya Caldera Complex, Nicaragua. Ph.D. Thesis, Dartmouth College, Hanover New Hampshire, pp. 1-169.

Wilson, L., Walker, G.P.L., 1987. Explosive volcanic eruptions-VI. Ejecta dispersal in plinian eruptions: the control of eruption conditions and atmospheric properties. Geophys. J. R. Astron. Soc. 89, 657-679. 